\title{
The Value of Bond Underwriter Relationships *
}

\author{
Stine Louise Daetz, Jens Dick-Nielsen and Mads Stenbo Nielsen
}

November 15, 2017

\begin{abstract}
We show that corporate bond issuers benefit from utilizing existing underwriter relationships when rolling over bonds, but at the same time become exposed to underwriter distress. A strong relationship enables the underwriter to credibly certify the issuer resulting in lower direct issuance costs and lower underpricing. However, if the underwriter becomes distressed, this spills over to the issuer's credit risk, because it weakens the relationship and increases the risk of involuntary relationship termination. The credit risk spillover is more pronounced for risky, opaque issuers with high rollover exposure, i.e., those issuers most in need of certification by an underwriter.
\end{abstract}

Keywords: Underwriter relationship; Corporate bonds; Certification; Rollover risk; Relationship banking JEL: G12; G14; G21; G24

${ }^{*}$ The authors are from Department of Finance at Copenhagen Business School (CBS). Corresponding author is Stine Louise Daetz (sld.fi@cbs.dk). We are grateful for helpful comments from Olivier Darmouni, Björn Imbierowicz, Nada Mora, Florian Nagler, Lasse Heje Pedersen, Ramona Westermann, Charlotte Østergaard, conference participants at 2015 MFA meeting, 2017 NFN workshop, and seminar participants at the FRIC seminar and PhD Seminar Day at CBS. The authors gratefully acknowledge support from the Center for Financial Frictions (FRIC), grant no. DNRF102. Stine Louise Daetz is also affiliated with Danmarks Nationalbank and it is hereby noted that the views expressed in this paper are those of the author(s) and do not necessarily reflect the position of Danmarks Nationalbank. 


\section{Introduction}

The value created by the relationship between an issuer of a security and the underwriter can be characterized as relationship capital (Rajan (1992), and James (1992)). Prior studies have shown that for equity offerings the issuer is able to capture part of the relationship capital value (Burch, Nanda, and Warther (2005), and Fernando, May, and

Megginson (2012)). However, the same studies do not find any evidence that the issuer of a corporate bond retains value from the underwriter relationship and loyalty towards the underwriter is therefore not rewarded. Contrary to this, we find that when bond underwriter relationships are weakened it affects corporate bond issuers negatively, implying that corporate bond issuers do derive value from underwriter relationship capital.

The role of a corporate bond underwriter is to facilitate the sales of newly issued corporate bonds. This includes determining the proper offering price and finding potential investors using the underwriter's investor connections (Nagler and Ottonello (2017)). There is ample evidence in the literature that the choice of bond underwriter will affect the success of the bond issue on the primary market (Fang (2005), Yasuda (2005), Andres, Betzer, and Limbach (2014), and Carbó-Valverde, Cuadros-Solas, and RodríguezFernández (2017)), as well as on the secondary market (Dick-Nielsen, Feldhütter, and Lando (2012)). Our results suggest that these benefits, at least partly, accrue due to a strong relationship between underwriter and issuer. The strong relationship can be seen in that the credit risk of the lead underwriter spills over to the credit risk of the issuing firm which is consistent with relationship capital being valuable for the issuer.

When issuers derive value from underwriter relationship capital it suggests that the issuers benefit from certification (Burch, Nanda, and Warther (2005)). In line with this 
argument, we show that certification by the lead underwriter is helpful in reducing asymmetric information between the issuer and the investors, ultimately resulting in a higher net price on the primary market (Fang (2005), and Carbó-Valverde, Cuadros-Solas, and Rodríguez-Fernández (2017)). While it is often true that some information such as credit ratings (Fernando, May, and Megginson (2012)) are available to investors, this does not satisfy investors. Certification is instrumental in finding the proper offering price and investor allocation; The Credit Roundtable (2015) reports that new bond issues are usually announced and priced (sold) within the same day, and usually with only very limited information available to the investors. The books can close as soon as 15 minutes after the announcement and the average is within 1 to 2 hours. While there used to be an issuer conference call for the bond investors to ask questions, the standard is now that there is no contact between the bond investor and the issuing firm. Investors may not even have the preliminary prospectus and bond indentures before the books are closed. The situations described by The Credit Roundtable (2015) highlight that bond investors are dependent upon the recommendation (certification) by the underwriter. Thus, it is crucial that the bond underwriter knows and has a strong relationship to the issuing firm in order to be able to credibly certify the bond issuance.

If the underwriter ends up in financial distress it weakens the underwriter's ability to connect the bond issuer with investors. Investors may no longer believe in the underwriter's skill to provide accurate recommendations if the underwriter itself is in distress. To enhance their own chances of short-term survival, distressed underwriters may even be prone to moral hazard resulting in biased recommendations. Thus, distress of the underwriter increases the risk that the issuers lose their valuable underwriter relationship capital. Consistent with this, we find empirically that underwriter distress affects the 
financial health of those firms with strong relationships to the underwriter. Our results show that establishing a new relationship to another underwriter with other investor connections is costly and the issuer would therefore, everything else equal, be worse off by switching underwriter. While firms may benefit from switching underwriter (see, e.g., Krigman, Shaw, and Womack (2001), and Fernando, Gatchev, and Spindt (2005)), this switch usually occurs voluntarily and not because of outside pressure. Ultimately, if an underwriter ends up in distress it takes time for the issuer to establish an equally good relationship to a new underwriter. We show that not utilizing an existing underwriter relationship when issuing bonds, in general, increases both the direct issuance costs, as well as the underpricing in the secondary market. These findings are in contrast to those of Burch, Nanda, and Warther (2005) who find no benefits of underwriter loyalty for corporate bond issuers.

For a given firm, we measure the distress of the issuer-underwriter relationship by first identifying the lead underwriters of all bonds currently outstanding. The credit default swap (CDS) spread of each lead underwriter, as a proxy for their credit risk, is then weighted in proportion to how many of the firms' currently outstanding bonds the underwriter has underwritten. Hence, our firm-specific relationship distress measure will be high if a dominant lead underwriter ends up in financial distress. Using this measure, we show that the firm-specific underwriter credit risk helps explain the CDS spreads, i.e., credit risk, of bond issuers, both in levels and in changes. Consistent with the certification hypothesis, we find that the sensitivity of firms' credit risk to underwriter distress is larger for speculative-grade issuers, i.e., exactly those who would benefit the most from certification. Furthermore, within our time period from 2004 to 2012 there are several large underwriters which default, most prominently, Bear Stearns, Lehman 
Brothers, and Wachovia. We show that there is a clear difference in the evolution of the credit risk for firms with a strong relationship to these underwriters compared to the rest of the market.

If the underwriter relationship capital is valuable, we expect underwriter distress to have a larger impact on firms with an imminent underwriting need. This would be the case for firms with a high fraction of short-term debt. Because firms usually rollover maturing debt, these firms would need to issue bonds again soon (Opler, Saron, and Titman (1997), Hovakimian, Opler, and Titman (2001)). We find support for this hypothesis as our results suggest that underwriter distress matters more for firms with a large amount of debt maturing over the coming year, i.e., firms with a high rollover exposure. Thus, our findings indicate that underwriter distress increases the rollover risk for bond issuers. Furthermore, we verify that the increased rollover risk is not caused by a more illiquid secondary market as in He and Xiong (2012).

The spill over from underwriter distress to the issuer's credit risk is statistically, as well as economically significant. While the first order determinants of issuer credit risk continues to be firm fundamentals, we find that variation in underwriter distress has the same explanatory power as variation in, e.g., firm leverage. For a firm with a median distressed underwriter relationship, underwriter distress can explain around $8 \%$ of the firm's credit spread. Contrary to this, Chen, Cui, He, and Milbradt (2017) calibrate the impact of rollover risk on the credit spread as defined in He and Xiong (2012). They find that rollover risk in their calibration accounts for $5 \%$ of the credit spread.

Our study is closely related to that of Burch, Nanda, and Warther (2005) and Fernando, May, and Megginson (2012). Burch, Nanda, and Warther (2005) find that switching bond underwriter decreases fees on average. However, their result is driven by issuers 
who voluntarily graduate to higher-quality underwriters while obtaining lower fees. In this study, we find the opposite result, namely, that switching underwriter increases fees and underpricing. The contrasting results hinge on the distribution of voluntary versus involuntary underwriter changes within the sample. To circumvent this issue, we take an approach similar to Fernando, May, and Megginson (2012) and Kovner (2012), and look at the effect of underwriter distress. In particular, Fernando, May, and Megginson (2012) investigate the impact of the Lehman Brothers default and find, in contrast to us, no significant impact for bond underwriter clients. However, as their paper only looks at the impact over the few days surrounding the default announcement and, thus, ignores any anticipation effect, the effect they find is a lower bound for the total impact of underwriter distress. Consistent with their results we find little incremental effect of the default itself. However, we do find a significant and large anticipation effect for bond issuers. Our underwriter relationship distress measure based on CDS spreads exactly measures the degree to which underwriter defaults are anticipated by the market.

Firms that seek to borrow money can broadly speaking choose between obtaining bank loans or issuing corporate bonds, and, accordingly, our study is also related to the banking literature. First, firms often choose bond underwriters based on their prior banking relations (Yasuda (2005), and Drucker and Puri (2005)). A distressed bond underwriter could therefore imply a distressed bank lending relationship. However, we verify empirically that bank loan underwriter distress (see, e.g., Acharya and Mora (2015)) and bond underwriter distress are separate contributors to issuer credit risk. Second, in the banking literature the role of a bank is often emphasized as being able to overcome asymmetric information about the quality and effort of the borrowing firm. In contrast, investors in the corporate bond market are assumed to rely only on public information 
(see, e.g., Diamond (1991), Rajan (1992), Besanko and Kanatas (1993), and Bolton and Freixas (2000)). Theoretically, firms with higher observable quality therefore go to the corporate bond market, while more risky and opaque firms choose to build a relationship with a bank. However, we show that this distinction is not clear cut and that bond issuers also benefit from certification.

\section{Underwriter Relationships and Issuance Costs}

Before we investigate the impact of underwriter distress on relationship capital, we look at the unconditional effect of switching underwriter. Underwriter distress is potentially costly for the bond issuer because it weakens the underwriter's ability to certify the issuer and connect the issuer to investors. To avoid this, the issuer could in principle just switch underwriter and, thereby, prevent any costs associated with having a distressed underwriter. However, this can only be done if bond issuers do not derive value from relationship capital. Burch, Nanda, and Warther (2005) show that it, in general, is costly to switch underwriter between equity offering, whereas Krigman, Shaw, and Womack (2001) and Fernando, Gatchev, and Spindt (2005) show that it, under some circumstances, can be beneficial. ${ }^{1}$ We investigate the potential benefits of loyalty for corporate bond issuers by looking at the gross spread paid to the underwriter for providing the underwriter service, as well as the underpricing in the secondary market.

To investigate the underwriter relationship benefits on gross spreads of corporate bonds, we collect the spread as a percentage of the offering price from FISD for all corporate bonds available. In the spirit of Gande, Puri, Saunders, and Walter (1997), we let the gross spread depend upon credit rating, bond type, issuer industry, time to ma-

\footnotetext{
${ }^{1}$ The authors show that firms may obtain additional and influential analyst coverage from the new lead underwriter and typically choose to graduate to higher reputation underwriters.
} 
turity, offering amount, and whether it is an issuance under rule 144a. Furthermore, we add a dummy for whether the issuer is utilizing an existing lead underwriter relationship. We label the dummy Existing UW Relation, and in our definition, the issuer is using an existing relationship if one or more lead underwriters involved in the new issuance also have been used for the issuance of a currently outstanding bond. We restrict the analysis to issuers classified as industrial by FISD and summary statistics are given in Table I, Panel A. More specifically, we look at the following regression:

$$
\begin{aligned}
& {\text { Gross } \operatorname{Spread}_{i}=\alpha+\beta_{1} \times \text { Existing UW Relation }}_{i}+\beta_{2} \times \text { Time to Maturity }_{i} \\
& +\beta_{3} \times \text { Offering } \text { Amount }_{i}+\beta_{4} \times \text { Rule } 144 \mathrm{a}_{i}+\beta_{5} \times \text { Bond Type }_{i}
\end{aligned}
$$

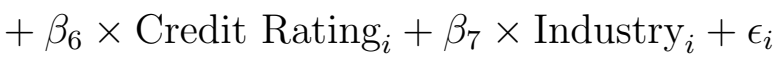

where $i$ is the $i$ 'th bond issue. ${ }^{2}$ The estimated regression coefficients can be seen in Table II. Looking at specification (a) and (b), we see that a larger issuance size and a shorter time to maturity both lowers the gross spread, and that issuing under Rule 144a is more expensive. However, we also see that using an existing relationship lowers the gross spread. In other words, switching underwriter, on average, is costly. In the special case of an initial public bond offering (IPO) the issuer does not, by definition, have any existing bond underwriter relationship. To address this, the third regression specification includes an IPO dummy. Consistent with the certification hypothesis, we find that IPOs have higher costs as the issuers in these types of offerings have no existing benchmarks or underwriter relationships. For seasoned issuances it is beneficial for the issuer to utilize existing underwriter relationship capital, rather than switching underwriter, as it lowers

\footnotetext{
${ }^{2}$ Bond Type and Industry are given on the levels available from FISD. Credit Rating is an indicator for investment-grade issuer versus speculative-grade issuer.
} 
the direct rollover costs for the issuer.

While the gross spread measures the direct issuance costs, we can also look at the implicit costs of underpricing in the secondary market (Cai, Helwege, and Warga (2007), and Nagler and Ottonello (2017)). We measure underpricing as the relative difference in prices between the average transaction price from TRACE over the first two weeks of trading and the offering price on the primary market. ${ }^{3}$ A positive underpricing return means that the bond is traded at higher prices on the secondary market compared to the primary market, which is an implicit cost for the issuer as known from the IPO literature. Using the same regression specifications as for gross spread, we see from Table II, specification (d) to (f) that utilizing an existing relationship also lowers the indirect issuance costs in the form of lower underpricing. ${ }^{4}$

Looking at the marginal regressions (a) and (d), the effect of having an underwriter relationship is quite significant. It lowers direct issuance costs by almost 20 basis points, i.e., from 103 bps to 84 bps, and it lowers underpricing from an average of 75 bps to 24 bps. For seasoned bond issuers approximately $60 \%$ of the bonds are issued using an existing underwriter relationship. In general, bond issuers can switch underwriter either because they are forced to do it or because they choose to do it. A forced shift of underwriter is most likely costly whereas a voluntary switch may be an advantage. The disadvantage we find from switching underwriter should therefore be interpreted as a lower bound for the costs of a forced new underwriter relationship across all bond issuers. In that regards, our contrasting findings compared to those in Burch, Nanda, and Warther (2005) are driven by sample difference in terms of the voluntary versus involuntary underwriter changes.

\footnotetext{
${ }^{3}$ Transaction prices from TRACE are cleaned as in Dick-Nielsen (2009).

${ }^{4}$ The results are robust to alternative specifications of the underpricing measure where we use shorter time windows of the trading period.
} 
In the following sections, we look at the impact of underwriter distress which is a more direct identification of the risk of being forced into a new relationship (see, e.g., Fernando, May, and Megginson (2012), and Kovner (2012)).

\section{Underwriter Distress and Issuer Credit Risk}

An involuntary switch of underwriter is most likely costly for the bond issuer, especially, if there is an imminent need for the underwriting service. In this section, we test to what extent underwriter distress can help explain issuer credit risk. We expect the sensitivity towards underwriter distress to be most pronounced for firms with high rollover exposure, as well as for opaque firms who stand to gain the most from certification. We first define an underwriter distress measure and, then, use this measure to test several hypotheses relating underwriter distress to the distress of their client firms.

\section{A. Underwriter Distress Measure}

Each corporate bond issuer has underwriter relationships to one or more banks. ${ }^{5}$ When measuring how distressed a firm's underwriter relationships are, it is important to differentiate between whether a given underwriter is core or periphery to the firm. We therefore count the firm's number of bonds currently outstanding that are underwritten by a particular underwriter. Based on this, we calculate the average CDS spread of all of the firm's underwriters weighted by the number of bonds they each have underwritten. In this way, we get an issuer-specific underwriter distress measure, UW Risk, where we proxy for underwriter distress by the underwriter's CDS spread. Hence, if several of a firm's bonds have been issued using a single underwriter, which typically is the case, then

\footnotetext{
${ }^{5}$ Every time we refer to underwriter we implicitly mean the lead underwriter(s) of the bond issuance in question. Most bonds are issued using only a single lead underwriter.
} 
that underwriter's CDS spread will be given a larger weight in the distress measure. The issuer-specific underwriter distress measure is defined as:

$$
\mathrm{UW} \mathrm{Risk}_{i t}=\frac{\sum_{j=1}^{N_{t}} \mathrm{UW} \mathrm{CDS}_{j t} \times \text { Number of bonds }_{i j t}}{\text { Total number of bonds }{ }_{i t}}
$$

where $i$ is the $i$ 'th issuer, $j$ is the underwriting bank, $\mathrm{UW} \mathrm{CDS}_{j t}$ is the five-year log $\operatorname{CDS}$ spread of the j'th underwriter in month $t$, and $N_{t}$ is the number of underwriter connections in month $t .{ }^{6}$ An underwriter may be close to default, but if that underwriter has only been used for the issuance of a tiny fraction of the bonds outstanding, then it should not matter much for the issuing firm. On the other hand, if the firm's main underwriter is in distress then this will have a large impact on the issuer-specific underwriter distress measure. In order to determine the lead underwriter relationships for each US corporate bond we use the Mergent FISD database. Table III shows the 20 most active underwriter banks for bonds outstanding at some point during the period 2004-2012. The most active underwriters (column 3) are JP Morgan, Citibank, and Goldman Sachs. Hence, these are the banks with the most corporate bond client firms during our sample period. We restrict our underwriter sample to the list of the 20 most active underwriter banks such that our empirical results do not get distorted by atypical underwriters which have only been used by very few issuers. For each of the top 20 underwriters, we collect CDS spread data from Markit. ${ }^{7}$

\footnotetext{
${ }^{6}$ Our results are robust to the alternative specification where each underwriter is weighted by the amount outstanding of each bond issue.

${ }^{7}$ Markit data is available from 2004 which thereby determines the starting point of our sample.
} 


\section{B. Firm Fundamentals and Market Data}

For all firms with a CDS spread in the Markit database, we collect quarterly firm fundamentals from Compustat (North America). As financial and utility firms often have special capital structures we exclude these from the analysis (SIC codes 4900 to 4999 and 6000 to 6999), as well as firms with no SIC code. The remaining firms constitute our sample of corporate bond issuers. Table III, Column 3, shows the number of client firms in the final sample for each of the top 20 underwriters. The distribution of underwriter relationships is almost the same as in the full sample except with fewer issuers. The reduction in client firms is mainly driven by the availability of CDS spreads. All CDS spreads are for the five-year CDS contract recorded at the beginning of the month. Therefore, our sample is naturally biased towards larger firms, i.e., firms with access to financing through corporate bonds and, furthermore, bond issuers with a CDS spread. This selection bias helps differentiating our sample from the typical banking relationship firm sample which usually consists of medium and smaller sized firms.

For the choice of potential determinants of issuer credit risk we largely follow Blanco, Brennan, and Marsh (2005), Collin-Dufresne, Goldstein, and Martin (2001), and Longstaff, Mithal, and Neis (2005) and collect a standard set of firm fundamentals from Compustat. $^{8}$ Leverage is measured as the book value of long-term debt plus debt in current liabilities, divided by total assets. Equity volatility is calculated using total stock returns for the preceding 90 days. Following Bates, Kahle, and Stulz (2009) and Subrahmanyam, Tang, and Wang (2017), we measure corporate cash holdings by the ratio of cash and cash equivalents to total assets. Firm size is measured by the logarithm of total assets. Profitability is measured as operating income to total revenue. Furthermore, we collect

\footnotetext{
${ }^{8}$ All quarterly data are interpolated to obtain monthly data.
} 
market wide variables to proxy for the business cycle. These are the one-year swap rate from the Federal Reserve Bank and the CDX index (CDX.NA.IG) provided by Markit. The CDX index is an average of the top industrial investment-grade CDS spreads. Table I, Panel B and C, provides summary statistics for all variables. Finally, we collect bond rating data from FISD and stock price information from CRSP.

\section{The Impact of Underwriter Distress}

If a financial institution, acting as an underwriter, is in distress it may not be able to assist client firms in issuing new bonds. This could impair future investment decisions in these firms and, in particular, make it costly for the firms to roll over maturing debt. The firms could potentially switch to a new underwriter, but this would also be costly as shown in the previous section. Furthermore, the firms may have other relationship ties to the underwriter which could amplify the effect of underwriter distress (we return to this issue in Section IV.). The expected implication for the issuing firm is that when the underwriter is in distress it will have a negative effect on the financial health of the issuing firm. Hence, the credit risk of the underwriter spills over to that of the issuing firm.

As a first rough indication of the impact of underwriter distress, we investigate the impact of the loss of an underwriter relationship, caused by the default of the underwriter. Figure I shows the time series of the bond issuing firms' average CDS spread based upon their existing underwriter relationships. We split the sample of issuers into two groups; those with a relationship to a defaulting underwriter, i.e., Bear Stearns, Lehman Brothers, or Wachovia, and those without. Figure I indicates that the group of bond-issuers with a connection to an underwriter which defaults is more credit risky than the other group.

In order to test this hypothesis more formally, we use the underwriter distress measure, 
UW Risk, defined above. We look at several versions of the following regression:

$$
\begin{aligned}
\operatorname{CDS~Spread}_{i t}= & \alpha+\beta \times \mathrm{UW} \mathrm{Risk}_{i t}+\text { Controls }_{i t}+\epsilon_{i t} \\
= & \alpha+\beta \times \mathrm{UW} \mathrm{Risk}_{i t}+\gamma_{1} \times \text { Leverage }_{i t}+\gamma_{2} \times \text { Equity Volatility }_{i t} \\
& +\gamma_{3} \times \text { Profitability }_{i t}+\gamma_{4} \times \text { Cash }_{i t}+\gamma_{5} \times \text { Firm Size }_{i t} \\
& +\gamma_{6} \times 1 \text { yr } \operatorname{Swap}_{t}+\gamma_{7} \times \operatorname{CDS~Index~}_{t}+\epsilon_{i t}
\end{aligned}
$$

where $i$ is the $i$ 'th issuing firm and $t$ is the month. We use a log transformation of the CDS spreads consistent with the approaches in both Ericsson, Jacobs, and Oviedo (2009) and Bai and $\mathrm{Wu}$ (2016). To mitigate the effect of potential outliers, we winsorize all variables at the 1 st and 99 th percentiles.

The results of this regression are listed in Table IV and the full sample refers to the sample that includes all available data from 2004 to 2012. In the first regression (specification (a)), we include underwriter distress as the only regressor. Our UW Risk measure is highly significant in this marginal specification, and the size of the coefficient on UW Risk is robust to including firm characteristics (specification (b)). The firm characteristics used here are leverage and equity volatility, which are known to be important predictors of credit risk (Merton, 1974) and have been shown to be the main predictors of CDS spreads (Ericsson, Jacobs, and Oviedo (2009) and Bai and Wu (2016)). We also add cash holdings, firm size, and profitability.

We expect that higher leverage and higher equity volatility implies higher credit risk, which is also what we see in Table IV. Furthermore, the results show that larger and more profitable firms are less credit risky, while firms with higher cash holdings are more credit risky. The latter finding is consistent with Harford, Klasa, and Maxwell (2014) who show 
that cash holdings are used as a buffer for risky firms when rolling over their debt.

While there is cross-sectional variation in the UW Risk measure, there is also a strong time series correlation with general market conditions. During the 2008 financial crisis both bond-issuing and bond-underwriting firms were constrained, independently of them having an underwriter relationship. Hence, when UW Risk is significant in the regression we could just be picking up this time series correlation. In order to control for this, we include the swap spread and a CDS index to take account of general market movements. This limits the sample to 2006 to 2014 because the CDS index is not available before 2006. In Table IV, we see that including the market variables reduces the influence of the UW Risk measure. However, the measure is still highly significant even after controlling for general market movements.

Since CDS spreads are not defined after a default, underwriters naturally exit our UW Risk measure calculation upon their default. However, excluding the relationship with a defaulted underwriter is counter-intuitive because we expect issuing firms to be affected the most by underwriter distress exactly in the case when the underwriter defaults. Instead, the UW Risk measure will by construction outline a drop after an underwriter defaults, as the remaining underwriter relationships are less credit risky. We specifically investigate the effect of an underwriter default in Section G., but, at this point, we merely exclude firms from the regression in the six months following the default of an underwriter. In Table IV, specification (d), we see that excluding these firm observations has very little impact on the estimated coefficients and, for now, we therefore continue to work with the sample where relationships to a defaulted underwriter are excluded. In overall, the results in Table IV support the hypothesis that underwriter distress spills over to the credit risk of the bond issuer. In Table $\mathrm{V}$, we run the same set of regressions, but this time we use 
changes instead of levels. Again, we see that the UW Risk measures is highly significant.

We can refine the connection between underwriter distress and bond issuer distress even further: To the extent that the underwriter certifies the quality of the bonds, a strong relationship should matter most for risky, opaque firms. These are the type of bond issuers who would benefit the most from certification, and also the type of issuer for whom we expect it to be most costly to build a new underwriter relationship. We therefore split the sample into investment-grade and speculative-grade rated bond issuers. Table VI shows that the UW Risk measure is highly significant for both investment-grade and speculative-grade rated issuers. However, the coefficient for issuers with a speculativegrade rating is larger both for the regression in levels and in changes. Thus, the results in Table VI indicate that the underwriter relationship, consistent with the certification hypothesis, is more important for riskier firms.

While we argue that the causality is a spill over from underwriter to bond issuer, one could also consider the reverse causality. If causality was reversed it would mean that excess risky firms choose more credit risky underwriters. ${ }^{9}$ However, we do not find evidence for such an effect in the data. The reverse causality is most easily investigated by considering the time series dimension. Before the crisis, Lehman Brothers was not significantly more risky than other underwriters. As Lehman Brothers' CDS spread rose during the crisis, reverse causality should then have implied that excess credit risky firms establish new underwriter relationships to Lehman Brothers. However, rather than finding this to be a dominant behavior, we find that relationships are very sticky. In particular, we observe that in the 12 months leading up to the default only 11 firms established new underwriter relationships to Lehman Brothers out of a total of 63 firms with a connection

\footnotetext{
${ }^{9}$ Excess risky in the sense that the firm's CDS spread could not be explained by the other controls in the regression, i.e., firm fundamentals and business cycle proxies.
} 
to Lehman Brothers. Furthermore, we find that these new firms are not excess credit risky at the inception of the relationship. In other words, those firms who experience an increase in credit risk because of a connection to Lehman Brothers had for the vast majority the connection also before Lehman Brothers became more credit risky than other underwriters. Hence, we do not find evidence for the presence of a reverse causality in our results.

\section{Rollover Risk}

Firms often aim at maintaining a target leverage ratio (Opler, Saron, and Titman (1997), and Hovakimian, Opler, and Titman (2001)) and, hence, often roll over maturing debt by replacing maturing bonds with newly issued bonds. In order to roll over bonds, firms need to make use of their underwriter relationship. If the underwriter is distressed, then the bond-issuing firms are exposed to higher costs when rolling over their debt which may further translate into higher credit risk (He and Xiong (2012)). It is therefore interesting to investigate to what extent the underwriter distress measure is specifically connected to rollover risk.

In order to test this rollover exposure hypothesis, we identify all firms with an imminent need for rolling over maturing debt. This is done by looking at the amount of long-term debt maturing within one year relative to total assets (as in He, Wang, and Qi (2014), and Harford, Klasa, and Maxwell (2014)). When this rollover exposure is high, we would expect underwriter distress to have a larger impact. ${ }^{10}$ We test the hypothesis by including the interaction between rollover exposure and the underwriter distress measure into the

\footnotetext{
${ }^{10}$ Again one could consider the reverse causality. However, the capital structure and, thus, rollover exposure is chosen at a point before there are any significant differences between underwriters' credit risk.
} 
regression from before:

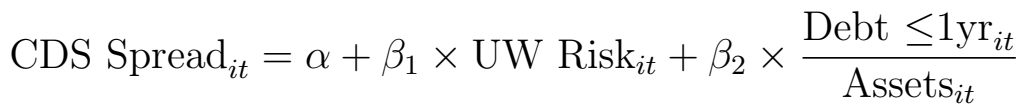

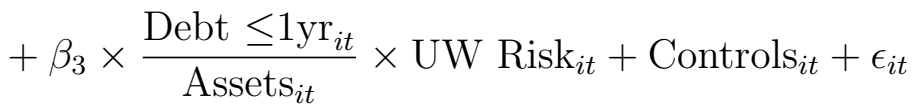

where $i$ is the $i$ 'th issuing firm and $t$ is the month. The controls are the same as in our base regression model (3). The coefficients are shown in Table VII. For brevity, and as all control variables are significant with the expected signs, we have excluded the coefficients for the control variables.

In Table VII, Panel A, specification (a) and (d), we see that when underwriter distress increases, the credit risk of bond issuers increases more for firms with higher rollover exposure. The coefficient is not significant for investment-grade firms but is significant for speculative-grade firms. When UW Risk is high enough, i.e., slightly above the median for speculative-grade firms, credit risk is also an increasing function of rollover exposure. Said in other words, as the amount of short-term debt increases so does the CDS spread as long as the underwriter distress measure is above a certain threshold. Related studies have shown that firms roll over part of their debt already two to three years before maturity (Xu (2017)). Therefore, we also investigate firms' holdings of long-term debt maturing within two and three years. For the two-year horizon the effect is still present (although the coefficients are smaller), whereas for the three-year horizon the results are insignificant. Hence, there seems to be an amplifying effect of higher rollover exposure, but when increasing the debt maturity horizon the effect gradually vanishes, intuitively, because the rollover exposure approaches total debt.

As a robustness check we look at an alternative definition of firms' rollover exposure 
calculated as maturing long-term debt scaled by total long-term debt instead of by total assets. The results are shown in Table VII, Panel B, and are very similar. In unreported results we also switch the five-year bond-issuer CDS spread with a one-year CDS spread. The results show that long-term debt due within one year remains significant for speculative-grade issuers, but that debt due within two and three years are not significant. This again supports the hypothesis that higher rollover exposure increases the sensitivity towards underwriter distress.

\section{E. Underwriter Distress and Bond Illiquidity}

Both theoretical (He and Xiong (2012)) and empirical (Valenzuela (2015), and Nagler (2017)) findings suggest that secondary market illiquidity could spill over to the primary market and induce rollover risk because of depressed offering prices. Hypothetically, this effect could be attributed to underwriter distress as well. Dick-Nielsen, Feldhütter, and Lando (2012) show that when the lead underwriter of a bond goes into distress, the bond becomes less liquid in the secondary market. This is because the underwriter often also acts as market maker in the secondary market. Since underwriter distress leads to a less liquid secondary market it would indirectly spill over into a price discount for new bonds on the primary market. This price discount is what is defined as rollover risk in He and Xiong (2012). Note that this market making hypothesis is complementary to the certification hypothesis, i.e., these are two different ways in which underwriter distress might impact issuer credit risk.

To test the market making hypothesis, we first verify that underwriter distress leads to a less liquid market (Dick-Nielsen, Feldhütter, and Lando (2012)) by estimating the 
following regression:

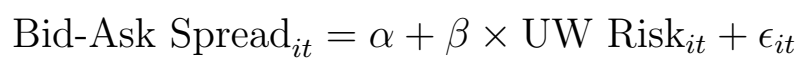

where $i$ is the $i$ 'th issuing firm and $t$ is the month. The bid-ask spread is calculated as the average effective bid-ask spread across all outstanding bonds from the same issuer. The bond specific bid-ask spread is calculated as the monthly average across the daily difference between volume weighted bid and ask transaction prices. ${ }^{11}$ From Table VIII, Panel A, we see that the UW Risk measure is significant in explaining the bid-ask spread so that higher underwriter distress leads to more illiquid bonds for the client firms. This suggests that part of the underwriter distress effect could be working through a spill over from a less liquid secondary market. To test whether there also exists a bond liquidity effect on corporate credit risk that is independent of underwriter distress, we first calculate the residual from the bid-ask spread regression specified in Equation (5), and then include this bid-ask spread residual in the base regression from Equation (4).

Table VIII, Panel B, first of all shows that bond issuers' bid-ask spreads on their own are significant in explaining issuer credit risk (specification (a)). That is, when the market becomes more illiquid, the issuer credit risk is higher consistent with the findings in Valenzuela (2015) and Nagler (2017). However, as we will show in the next section, the impact from illiquidity is not economically significant despite being statistically significant. Thus, while we do find evidence for positive correlation between bond liquidity and corporate credit risk, we do not find strong support for the market making hypothesis in our sample.

\footnotetext{
${ }^{11}$ We only use institutional size transactions above $\$ 100,000$ as in Bessembinder, Kahle, Maxwell, and $\mathrm{Xu}$ (2009).
} 
In the remaining specifications in Panel B we include the bid-ask spread residual instead of the bid-ask spread directly. The results show that in all specifications, underwriter distress remains significant. In some of the specifications the bid-ask spread residual also comes out as significant, while the interaction between the firm's rollover exposure and the bid-ask spread residual never comes out significant. It is mainly this latter interaction which has been taken as evidence that rollover risk (in the sense of He and Xiong (2012)) matters for issuer credit risk. Thus, in contrast to the related literature our results suggest that the market maker effect is small in our sample and, furthermore, to a large extent is due to underwriter distress causing the bonds to be less liquid in the secondary market.

\section{F. Economic Significance}

So far, we have shown that underwriter distress contributes significantly to explaining the credit risk of bond issuers. In this section we further investigate whether the effect is also economically significant. We evaluate the economic impact by investigating how much of the variation in issuer credit risk that can be explained by variation in underwriter distress. If large differences in underwriter distress also lead to large differences in CDS spreads of bond issuers, then we will conclude that the effect is economically significant.

Using the regression specification from Table VIII, specification (c), we calculate the contribution of our underwriter distress measure for each issuer, $i$, and each month, $t$, as follows:

$$
\begin{aligned}
& \mathrm{UW} \mathrm{Risk} \mathrm{contribution}_{i t}=\hat{\beta}_{1} \times \mathrm{UW} \mathrm{Risk}_{i t}+\hat{\beta}_{3} \times \frac{{\text { Debt } \leq 1 \mathrm{yr}_{i t}}_{\text {Assets }_{i t}} \times \mathrm{UW} \mathrm{Risk}}{i t} \\
&=\text { CDS Spread } \\
& i t- \text { Non-UW Risk variables } \\
& i t
\end{aligned}
$$

After having calculated the underwriter distress contribution for each CDS spread obser- 
vation we calculate the distribution of this contribution across time and issuers. Following the approach in Dick-Nielsen, Feldhütter, and Lando (2012), we then calculate the width of the distribution by looking at the difference between the $50 \%$ percentile and the $5 \%$ percentile:

\section{UW Risk contribution ${ }^{50 \%}$ - UW Risk contribution ${ }^{5 \%}$}

This difference can be interpreted as the part of the variation in the CDS spread, between an issuer with a median distressed underwriter and an issuer with a minimum distressed underwriter, which can be explained by the difference in underwriter distress. ${ }^{12}$ We split the sample into issuers with an investment-grade rating versus a speculative-grade rating and form separate distributions for each of these rating classes.

Table IX, Panel A, shows the estimates of economic significance (distribution widths) of the underwriter distress measure, as well ad of some of the other control variables. Relative to each of the other variables, the impact from underwriter distress is rather large. However, the combined effect of all firm fundamentals is still larger than the underwriter distress effect (although adding up the individual effects of fundamental variables ignores possible correlation). Since the log difference can be interpreted as a relative difference, we can see that the underwriter distress impact is approximately $35 \%$ larger for an investment-grade rated median underwriter-distressed bond issuer compared to an issuer with a minimum distressed underwriter. The effect for speculative-grade firms is larger at $46 \%$.

Another way to evaluate the impact, also following Dick-Nielsen, Feldhütter, and

\footnotetext{
${ }^{12}$ This approach is essentially equivalent to evaluating the impact of, for example, a one standard deviation shock to UW Risk. However, it should be more robust as it controls for possible covariation between UW Risk and other independent variables.
} 
Lando (2012), is to measure the underwriter distress contribution relative to the size of the total issuer CDS spread. We therefore calculate the relative spread contribution as follows:

$$
\frac{\text { UW Risk contribution }_{i t}-\mathrm{UW} \mathrm{Risk} \mathrm{contribution}^{5 \%}}{\text { CDS Spread }_{i t}}
$$

where $i$ is the $i$ th issuer and $t$ is the month. Finally, we form the distribution of this ratio and look at the median of the distribution. Table IX, Panel B, shows the median numbers for investment-grade and speculative-grade rated firms. Using this approach we see that underwriter distress explains around $8 \%$ of the total credit risk for both investment-grade and speculative-grade firms. This fraction is again comparable to the best single firm fundamentals factor. It can also be compared to the credit spread contribution of $5 \%$ from rollover risk in Chen, Cui, He, and Milbradt (2017).

Note that the bond illiquidity residual can only explain around $1 \%$ of the spread. Since the coefficient on bid-ask spread alone in the regressions in Table VIII was twice that of the residual, then illiquidity cannot explain more than $2 \%$ of the credit spread. Hence, the economic impact of the market making hypothesis is rather small compared to the total effect of underwriter distress of around $8 \%$.

\section{G. Default of an Underwriter}

Most of the previous tests have excluded the CDS spread of an issuing firm if it had an underwriter default within the past six months (except Tables IV and V). This was done because underwriter default is a rare event which could be biasing results when analyzing

issuer distress after an underwriter defaults. In this section, we revisit the effect of having an underwriter defaulting. 
The underwriter distress measure does at all times consist of the CDS spreads of underwriters 1) who are currently alive, i.e., not in default, and 2) with whom the firm currently has bonds outstanding. Hence, the measure has the counter-intuitive behavior that right after an underwriter defaults the underwriter distress measure will most likely improve because the riskiest underwriter is taken out. This is counter-intuitive as we would think that the loss of an underwriter is the ultimately worst case of underwriter distress. Given a default of an underwriter relationship the firm is forced to build a new relationship (or tighten the relationships with other existing underwriters). Furthermore, the default of an underwriter is likely to happen when the market and other underwriters are distressed as well.

We consider three specific cases where an underwriter defaulted or experienced a situation similar to a default. First, we consider the default and takeover of Bear Stearns in March 2008. Second, we consider the default of Lehman Brothers. After some turmoil starting in August 2008, Lehman Brothers defaulted in September 2008. Third, we look at Wachovia. In April 2008, Wachovia reported large losses and ended up being acquired by Citigroup in September 2008. The most important dates and events for each of these underwriter defaults are listed in Table X.

Figure III shows the time series of the average CDS spread for firms with an underwriter relationship to Bear Stearns, Lehman Brothers, and Wachovia, respectively. ${ }^{13}$ In each sub-figure, the sample of firms is split into two types of bond-issuers; those with an underwriter relation to Bear Stearns, Lehman Brothers, or Wachovia, respectively, at the point of their defaults, and those without a relation to any of these underwriters (control group). After normalizing the average CDS spread of the sub-samples to the same starting

\footnotetext{
${ }^{13}$ In order to provide a clearer study, we exclude in this analysis all firms that had a relationship to more than one of the three defaulted underwriters.
} 
point, we see from Figure III that the group with a defaulted underwriter is more credit risky than the control group.

Similar to the former regressions, we tease out the effect of a defaulting underwriter by looking at the regression specification from Equation (4). Now we also include firms that have had an underwriter defaulting within the last six months, but control for this by adding a time-dependent dummy to the regression in the following way. For the default of Lehman Brothers, we add a dummy variable which is equal to 1 only in the first month after the default of Lehman Brothers, and only if the issuer had an underwriter relationship with Lehman Brothers. We subsequently replace this dummy with another dummy which is equal to 1 in the two month following the default etc., all the way up to 6 months after the default. These dummies account for the special circumstances of losing an underwriter relationship after a default over different time horizons. We produce the same dummies for the default of Bear Stearns and the default of Wachovia. Table XI shows the estimates from these regressions. The table only reports the coefficient for the default dummy for each of the regressions.

The defaulting underwriter coefficient is significant for the first three to five months after the default. This indicates that the credit risk of the issuer is at an elevated level right after the elimination of an underwriter relationship. As we extend the time horizon of the default dummy the issuing firm has time to build new relationships. The combined effect of the increase in CDS spread from the dummy and the drop in UW Risk from eliminating the riskiest underwriter almost cancels out in the sense that the drop in the UW Risk measure is offset by the increase in the dummy. Thus, the resulting issuer credit spread is fairly constant at the level from when the underwriter defaulted. The credit spread then improves after four to six months at which point the underwriter distress measure for the 
issuer's remaining underwriters is no longer affected by the default event.

It is difficult to extrapolate too much from these three default events. First, defaults are rare. Second, the types of default differ significantly from each other. Both Bear Stearns and Wachovia are effectively taken over immediately by other firms. The issuing firms then need to rebuild their relationship with the new owners. On the other hand, for the case of Lehman Brothers there is no one who takes over their responsibilities. Therefore, it would be natural to expect that this default had a larger impact on issuer credit risk than the other two events, but this does not seem to be the case. Figure III reveals that the elevated level of credit risk maybe last slightly longer, but it is not materially different. This may be caused by the fact that all other underwriters at the same time experience a large shock to their default risk and becomes distressed. In other words, as the entire market is distressed it may be difficult to distinguish the underwriter risk of one issuer from that of another issuer.

\section{Bond Underwriter versus Bank Loan Provider}

The bond issuer underwriter relationship is different from the traditional banking relationship. The syndicate members in a bank loan directly contribute funds to finance the loan whereas the bond underwriter primarily acts as an intermediary. However, it is common for the bond issuer to find its underwriter among existing banking relationships (Yasuda (2005)). The underwriter distress effect we find could therefore be a proxy for a distressed banking relationship. As a robustness test and, in order to separate the two effects, we construct a bank loan relationship distress measure similar to the underwriter

distress measure. For each firm we collect information on syndicated loans from SDC Dealscan and the bank loan distress measure is then the weighted average of the syn- 
dicate members' five-year log CDS spread for all loans currently outstanding. We limit the banks to the same list of top 20 underwriter banks that we used for the underwriter distress measure but we add any top 20 syndicate bank which was not part of the bond underwriter sample (see Table III).

In order to distinguish between a firm's dependence on its bank loan connection versus its bond underwriter connection, we multiply the underwriter distress measure with the ratio of outstanding corporate bond debt to the sum of bond and bank loan debt and, similarly, multiply the bank distress measure with the fraction of outstanding bank loan debt. The idea is that if corporate bond debt only accounts for a small fraction of the overall debt, then it is unlikely that the underwriter relationship should be important compared to the bank loan relationship, and vice versa. Table I, Panel D, reports summary statistics for the sample and shows that the dependence upon bank loan debt is rather evenly distributed between firms with low and high dependence, respectively.

We add the two distress measures along with the bond debt fraction to the base regression from Equation (3). The results are reported in Table XII. The coefficient on the bond debt fraction is negative, indicating that firms financed with more corporate bond debt compared to bank debt are less risky. This is consistent with the idea that more opaque firms seek out a banking relationship (see, e.g., Rajan (1992)). However, for the firms with a high bond debt fraction, we see that underwriter risk is equally important. Both the underwriter risk and the bank risk coefficients are significant, i.e., both types of relationships impact the credit risk of the firms. Which of the two types of relationships is most important in the end then depends on the primary financing source for the specific firm. 


\section{Conclusions}

We show that corporate bond issuers derive value from bond underwriter relationship capital. When a bond issuer utilizes an existing underwriter relationship, it lowers both the indirect and direct issuance costs. Furthermore, issuers are adversely affected by underwriter distress and the credit risk of the underwriter spills over to the credit risk of the issuer. We show this by constructing an issuer specific measure of underwriter distress. This measure captures the average weighted stress of the issuer's underwriter connections. Our findings suggest that bond underwriters benefit from certification by the underwriter. Consistent with this hypothesis, we show that the effect of underwriter distress is stronger for speculative-grade rated firms which are usually also more opaque and, therefore, more dependent upon certification. The impact of underwriter distress is also stronger for firms with a high fraction of short-term debt, i.e., firms with an imminent

need for underwriter services for rolling over maturing bonds. Thus, underwriter distress can be characterized as a rollover risk for the issuer. 


\section{References}

Acharya, Viral, and Nada Mora, 2015, A crisis of banks as liquidity providers, Journal of Finance $70,1-43$.

Andres, Christian, André Betzer, and Peter Limbach, 2014, Underwriter reputation and the quality of certification: Evidence from high-yield bonds, Journal of Banking and Finance 40, $97-115$.

Bai, Jennie, and Liuren $\mathrm{Wu}, 2016$, Anchoring credit default swap spreads to firm fundamental, Journal of Financial and Quantitative Analysis 51, 1521-1543.

Bates, Thomas, Kathlen Kahle, and Rene Stulz, 2009, Why do us firms hold so much more cash than they used to?, Journal of Finance 64, 1985-2021.

Besanko, David, and George Kanatas, 1993, Credit market equilibrium with bank monitoring and moral hazard, Review of Financial Studies 6, 212-232.

Bessembinder, Hendrik, Kathleen Kahle, William Maxwell, and Danielle Xu, 2009, Measuring abnormal bond performance, Review of Financial Studies 22, 4219-4258.

Blanco, Roberto, Simon Brennan, and Ian W. Marsh, 2005, An empirical analysis of the dynamic relation between investment-grade bonds and credit default swaps, Journal of Finance 60, $2255-2281$.

Bolton, Patrik, and Xavier Freixas, 2000, Equity, bonds, and bank debt: Capital structure and financial market equilibrium under asymmetric information, Journal of Political Economy $108,324-351$.

Burch, Timothy, Vikram Nanda, and Vincent Warther, 2005, Does it pay to be loyal? An empirical analysis of underwriting relationships and fees, Journal of Financial Economics 77, 673-699.

Cai, Kelly, Jean Helwege, and Arthur Warga, 2007, Underpricing in the corporate bond market, Review of Financial Studies 20, 2012-2046.

Carbó-Valverde, Santiago, Pedro Cuadros-Solas, and Francisco Rodríguez-Fernández, 2017, Do banks and industrial companies have equal access to reputable underwriters in debt markets?, Journal of Corporate Finance 45, 176-202.

Chen, Hui, Rui Cui, Zhiguo He, and Konstantin Milbradt, 2017, Quantifying liquidity and default risks of corporate bonds over the business cycle, Review of Financial Studies, forthcoming.

Collin-Dufresne, Pierre, Robert S. Goldstein, and J. Spencer Martin, 2001, The determinants of credit spread changes, Journal of Finance 56, 2177-2207. 
Diamond, Douglas, 1991, Monitoring and reputation: The choice between bank loans and directly placed debt, Journal of Political Economy 99, 689-721.

Dick-Nielsen, Jens, 2009, Liquidity biases in trace, Journal of Fixed Income 19, 43-55.

— - Peter Feldhütter, and David Lando, 2012, Corporate bond liquidity before and after the onset of the subprime crisis, Journal of Financial Economics 103, 471-492.

Drucker, Steven, and Manju Puri, 2005, On the benefits of concurrent lending and underwriting, Journal of Political Economy 60, 2763-2799.

Ericsson, Jan, Kris Jacobs, and Rodolfo Oviedo, 2009, The determinants of credit default swap premia, Journal of Financial and Quantitative Analysis 44, 109-132.

Fang, Lily Hua, 2005, Investment bank reputation and the price and quality of underwriting services, Journal of Finance 60, 2729-2761.

Fernando, Chitru, Vladimir Gatchev, and Paul Spindt, 2005, Wanna dance? How firms and underwriters choose each other, Journal of Finance 60, 2437-2469.

Fernando, Chitru, Anthony May, and William Megginson, 2012, The value of investment banking relationships: Evidence from the collapse of Lehman Brothers, Journal of Finance 67, 235270 .

Gande, Amar, Manju Puri, Anthony Saunders, and Ingo Walter, 1997, Bank underwriter of debt securities: Modern evidence, Review of Financial Studies 10, 1175-1200.

Harford, Jarrad, Sandy Klasa, and William Maxwell, 2014, Refinancing risk and cash holdings, Journal of Finance 69, 975-1012.

He, Zhiguo, Yuan Wang, and Yaxuan Qi, 2014, Does bond liquidity affect financial contracts?, Working Paper University of Chicago.

He, Zhiguo, and Wei Xiong, 2012, Rollover risk and credit risk, Journal of Finance 68, 391-429.

Hovakimian, A., T. Opler, and S. Titman, 2001, The debt-equity choice: An analysis of issuing firms, Journal of Financial and Quantitative Analysis 36, 1-24.

James, Christopher, 1992, Relationship-specific assets and the pricing of underwriter services, Journal of Finance 47, 1865-1885.

Kovner, Anna, 2012, Do underwriters matter? The impact of the near failure of an equity underwriter, Journal of Financial Intermediation 21, 507-529.

Krigman, Laurie, Wayne Shaw, and Kent Womack, 2001, Why do firms swith underwriters?, Journal of Financial Economics 60, 245-284. 
Longstaff, Francis A., Sanjay Mithal, and Eric Neis, 2005, Corporate yield spreads: Default risk or liquidity? New evidence from the credit default swap market, Journal of Finance 60, $2212-2253$.

Merton, Robert, 1974, On the pricing of corporate debt: The risk structure of interest rates, Journal of Finance 29, 449-470.

Nagler, Florian, 2017, Yield spreads and the corporate bond rollover channel, Working paper Bocconi University.

_ and Giorgio Ottonello, 2017, Structural changes in corporate bond underpricing, Working Paper Bocconi University.

Opler, Tim, Michael Saron, and Sheridan Titman, 1997, Designing capital structure to create shareholder value, Applied Corporate Finance 64, 21-32.

Rajan, Raghuram, 1992, Insiders and outsiders: The choice between informed and arm's-length debt, Journal of Finance 47, 1367-1400.

Roundtable, The Credit, 2015, Corporate bond underwriting and distribution practices, Presentation to the U.S. Securities and Exchange Commission.

Subrahmanyam, Marti G., Dragon Y. Tang, and Sarah Q. Wang, 2017, Credit default swaps, exacting creditors and corporate liquidity management, Journal of Financial Economics 124, $395-414$.

Valenzuela, Patricio, 2015, Rollover risk and credit spreads: Evidence from international corporate bonds, Review of Finance 20, 631-661.

Xu, Qiping, 2017, Kicking maturity down the road: Early refinancing and debt maturity management in the corporate bond market, Review of Financial Studies, R\&R.

Yasuda, Ayako, 2005, Do bank relationships affect the firm's underwriter choice in the corporatebond underwriting market?, Journal of Finance 60, 1259-1292. 


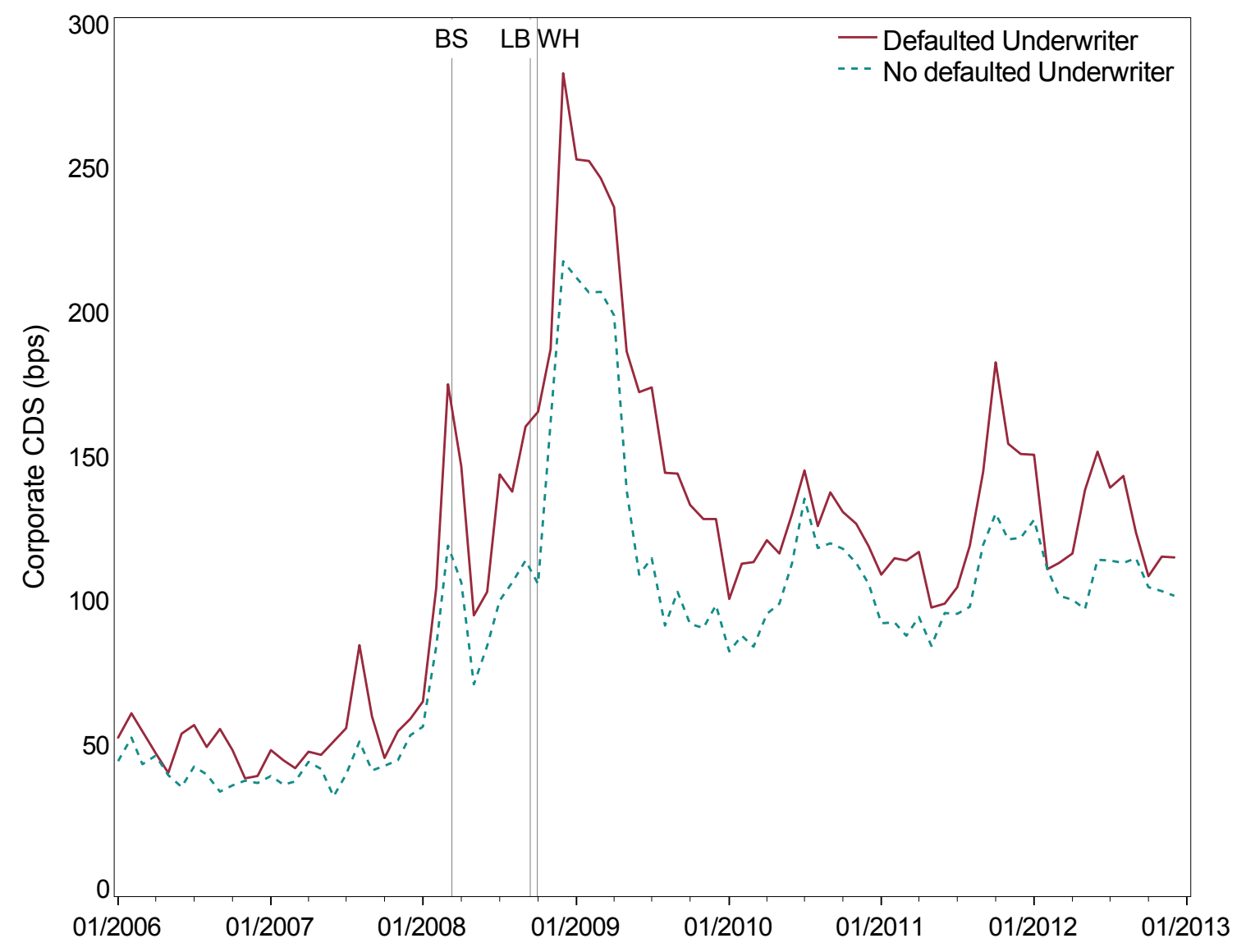

Figure I

CDS Spreads of Corporate Bond Issuers

The figure shows the development in the CDS spreads of US-based firms for the period 2006 to 2012. The CDS spread is the average (median) of monthly primo-months observations of five-year CDS spreads, given in basis points. Issuers are separated into 'Defaulted Underwriter' and 'No Defaulted Underwriter' samples based upon whether the firm had a relationship to an underwriter that defaulted within the sample period. Specifically, the figure includes the issuer relationships to top-20 underwriters within the sample period, where the sub-sample of defaulted underwriters includes the default of Bear Stearns (BS) on March 14, 2008, Lehman Brothers (LB) on September 15, 2008, and Wachovia (WH) on September $29,2008$. 

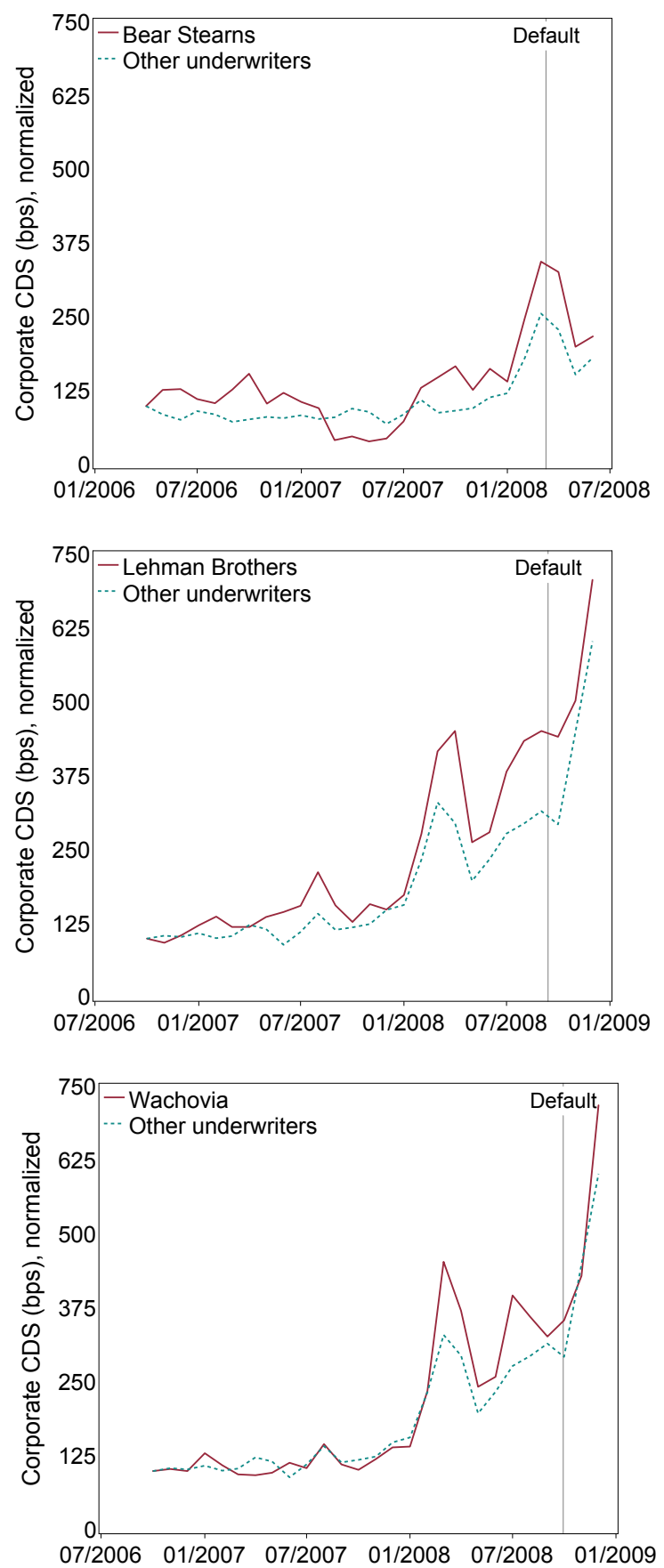

Figure III

The Impact of Underwriter Default on Issuer CDS Spreads

The figures show the development in the CDS spreads of firms that have an underwriter relationship to Bear Stearns, Lehman Brothers or Wachovia, as well as for firms that do not have an underwriter relationship to these underwriters. Bear Stearns defaulted on March 14, 2008, Lehman Brothers defaulted on September 13, 2008, while Wachovia defaulted on September 29, 2008. The CDS spread is the median beginning of month five-year CDS spread in bps across issuers in the sample. The average CDS spread of each sub-sample is normalized to the same starting point two years before the default of the respective underwriter. 
Table I

\section{Summary Statistics}

This table provides summary statistics for all regression variables. Gross spread is the issuance costs as a fraction of offering price from FISD. Underpricing is the relative price difference between the offering price and the average transaction price over the two weeks after issuance. Existing UW Relation is a dummy which is 1 if one or more lead underwriters for the new issuance have also been used for an currently outstanding bond. IPO is a dummy which is 1 if it is the first bond issuance by the firm. Time to maturity is measured in years. Offering amount is log offering amount in millions. Rule 144a is a dummy which is 1 if the bond was issued under Rule 144a. The CDS Spread is the five-year beginning of month observation. UW Risk is the log of the average related underwriter CDS spread weighted by number of outstanding bonds underwritten for each issuer. Leverage is the book value of long-term debt plus debt in current liabilities divided by total assets. Equity volatility is calculated using total stock returns for the preceding 90 days. Firm size is log total assets. Profitability is operating income to total revenue. Cash is the ratio of cash and cash equivalents to total assets. UW Relations is the number of underwriter relations of the average firm across time. Bonds outstanding is the number of bonds held by the average firm across time. 1 yr Swap is the 1 year swap rate from the Federal Reserve Bank. CDS Index is the $\log$ CDX.NA.IG index spread provided by Markit. Investment-grade (Speculative-grade) refers to a firm with a S\&P credit rating that is equal to 'BBB' or higher ('BB' or lower). The sample period is 2004-2012, and the variables are based on monthly observations. The data are obtained from Compustat N.A., CRSP, FISD, TRACE, Markit, and SDC Dealscan.

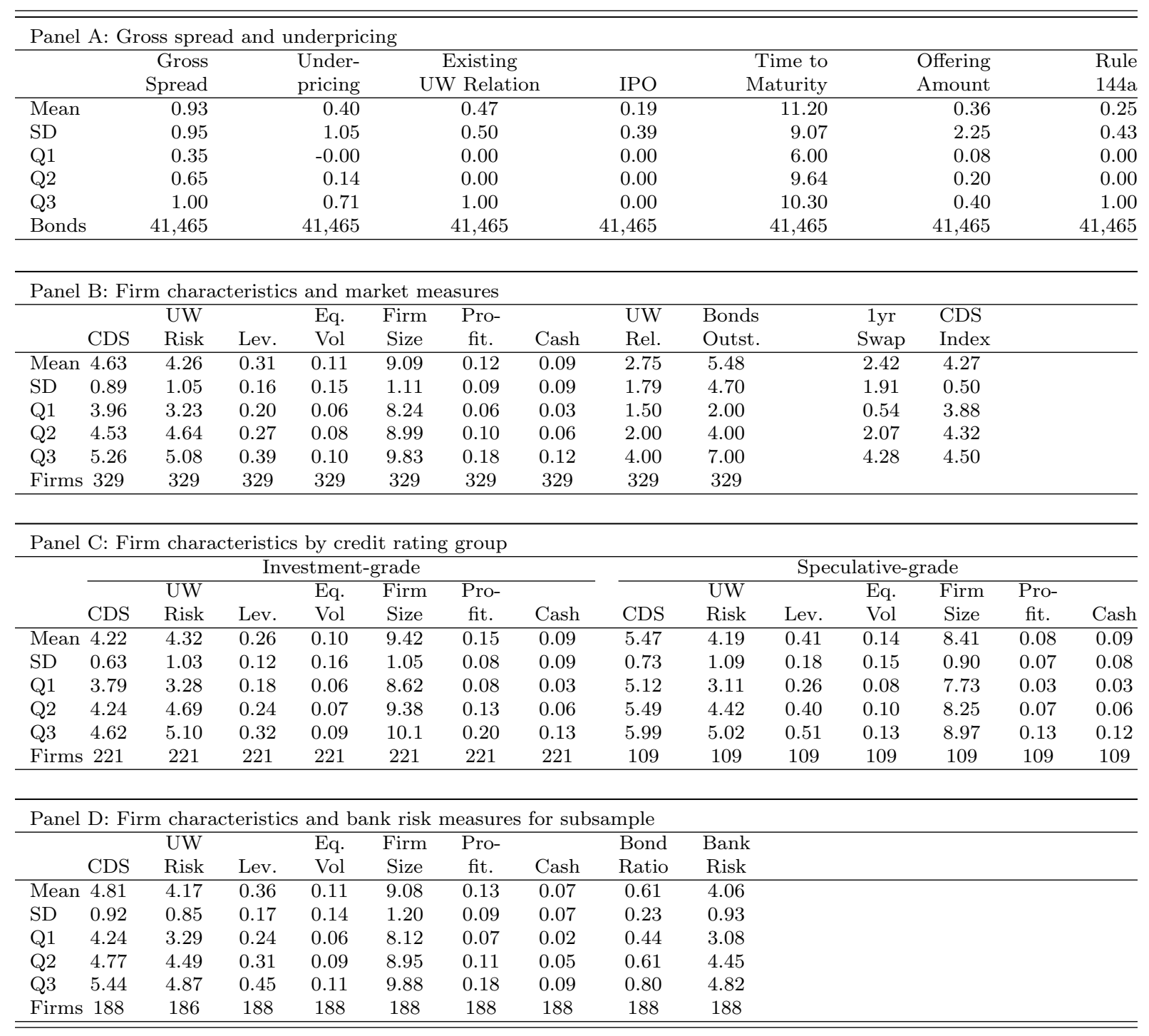


Table II

\section{Underwriter Relation Effect on Gross Spread and Underpricing}

This table shows the impact of utilizing an existing underwriter relationship on the gross spread and underpricing. Gross Spread is the fees paid to underwriter as a fraction of the offering price. Underpricing is defined as the return between the offering price and the average price over the first two weeks of trading on the secondary market. Exisitng UW Relation is a dummy which is 1 if the bond is issued using an underwriter which has also been used for another currently outstanding bond from the same firm. The IPO dummy is 1 if the bond issue is the first for the company. For gross spread (in percentage points), we use all bonds from FISD and for underpricing (in percentage points) we use all bonds available in TRACE. (*** denotes significance at the $1 \%$ level, $* *$ at the $5 \%$ level, and * at the $10 \%$ level. The numbers in parentheses are t-statistics.)

\begin{tabular}{|c|c|c|c|c|c|c|}
\hline & \multicolumn{3}{|c|}{ Gross Spread } & \multicolumn{3}{|c|}{ Underpricing } \\
\hline & (a) & (b) & (c) & (d) & (e) & (f) \\
\hline Intercept & $\begin{array}{c}1.030^{* * *} \\
(106.39)\end{array}$ & & & $\begin{array}{c}0.747^{* * *} \\
(34.49)\end{array}$ & & \\
\hline Existing UW Relation & $\begin{array}{c}-0.194 * * * \\
(-14.14)\end{array}$ & $\begin{array}{c}-0.237 * * * \\
(-17.26)\end{array}$ & $\begin{array}{c}-0.077 * * * \\
(-5.54)\end{array}$ & $\begin{array}{c}-0.509 * * * \\
(-19.32)\end{array}$ & $\begin{array}{c}-0.167 * * * \\
(-6.39)\end{array}$ & $\begin{array}{c}-0.079 * * * \\
(-2.88)\end{array}$ \\
\hline Time To Maturity & & $\begin{array}{c}0.004^{* * *} \\
(6.39)\end{array}$ & $\begin{array}{c}0.007^{* * *} \\
(10.88)\end{array}$ & & $\begin{array}{c}0.003^{* *} \\
(2.43)\end{array}$ & $\begin{array}{c}0.004^{* * *} \\
(2.86)\end{array}$ \\
\hline Offering Amount & & $\begin{array}{c}-0.004^{*} \\
(-1.91)\end{array}$ & $\begin{array}{l}-0.003 \\
(-1.22)\end{array}$ & & $\begin{array}{c}0.115^{* * *} \\
(4.93)\end{array}$ & $\begin{array}{c}0.130 * * * \\
(5.61)\end{array}$ \\
\hline Rule $144 \mathrm{a}$ & & $\begin{array}{c}0.194^{* * *} \\
(5.77)\end{array}$ & $\begin{array}{l}0.036 \\
(1.09)\end{array}$ & & $\begin{array}{c}0.405^{* * *} \\
(12.38)\end{array}$ & $\begin{array}{c}0.312^{* * *} \\
(9.14)\end{array}$ \\
\hline IPO Dummy & & & $\begin{array}{c}0.699 * * * \\
(38.50)\end{array}$ & & & $\begin{array}{c}0.408^{* * *} \\
(9.14)\end{array}$ \\
\hline Bond Type Dummy & No & Yes & Yes & No & Yes & Yes \\
\hline Credit Rating Dummy & No & Yes & Yes & No & Yes & Yes \\
\hline Industry Dummy & No & Yes & Yes & No & Yes & Yes \\
\hline$R^{2}$ & 0.010 & 0.310 & 0.360 & 0.051 & 0.296 & 0.304 \\
\hline $\mathrm{N}$ & 19257 & 19107 & 19107 & 6992 & 6990 & 6990 \\
\hline
\end{tabular}


Table III

Top-20 Bond Underwriters (2004-2012)

This table presents the 20 most active banks serving as underwriters of corporate bonds outstanding in the period from 2004 to 2012. The list counts the number of US corporate bond issuances were the respective financial institution acted as the lead underwriter. The number of clients in column b refers to the number of non-financial firms that issued bonds using the given underwriter, while the number of clients in column $\mathrm{c}$ is the firms within our sample.

\begin{tabular}{|c|c|c|c|}
\hline $\begin{array}{l}\text { Financial institution } \\
\text { (Lead underwriter) }\end{array}$ & $\begin{array}{l}\text { Country } \\
\text { of origin } \\
\text { (a) }\end{array}$ & $\begin{array}{c}\begin{array}{c}\text { Number of clients } \\
\text { within sample period }\end{array} \\
\text { (b) }\end{array}$ & $\begin{array}{l}\begin{array}{c}\text { Number of clients } \\
\text { within firm sample }\end{array} \\
\text { (c) }\end{array}$ \\
\hline ABN Amro Bank & NLD & 60 & 6 \\
\hline Banc of America & USA & 1419 & 109 \\
\hline Barclays & GBR & 633 & 32 \\
\hline Bank One & USA & 71 & 7 \\
\hline BNP Paribas & FRA & 170 & 10 \\
\hline Bear Stearns & USA & 239 & 9 \\
\hline Canadian Imperial Bank of Commerce & CAN & 34 & 1 \\
\hline Citibank & USA & 1743 & 123 \\
\hline Credit Suisse & CHE & 884 & 57 \\
\hline Deutsche Bank & GER & 909 & 61 \\
\hline Goldman Sachs & USA & 1605 & 68 \\
\hline HSBC Bank & GBR & 200 & 7 \\
\hline JP Morgan & USA & 2610 & 143 \\
\hline Lehman Brothers & USA & 910 & 42 \\
\hline Merrill Lynch & USA & 1270 & 59 \\
\hline Morgan Stanley & USA & 1324 & 66 \\
\hline Salomon Brothers & USA & 563 & \\
\hline Union Bank of Switzerland & CHE & 615 & \\
\hline Wells Fargo & USA & 365 & 23 \\
\hline Wachovia & USA & 433 & 28 \\
\hline
\end{tabular}


Table IV

\section{Underwriter Distress Effect on Credit Risk}

This table shows the impact of underwriter distress on issuer credit risk. CDS Spread is the log CDS spread on the five-year contract for the issuing firm. UW Risk is the log of the related underwriters' average CDS spreads weighted by the number of underwritten bonds outstanding. Specification (d) excludes observations for firms where one of the related underwriters has defaulted within the latest 6 months. The main sample period is 2004-2012, based on monthly observations. When using market measures, the sample period is reduced to 2006-2012 due to lack of data availability. (*** denotes significance at the $1 \%$ level, ${ }^{* *}$ significance at the $5 \%$ level, and ${ }^{*}$ significance at the $10 \%$ level. The numbers in parentheses are t-statistics.)

\begin{tabular}{|c|c|c|c|c|}
\hline & \multicolumn{4}{|c|}{ CDS Spread } \\
\hline & $\begin{array}{l}\text { Full sample } \\
\text { (a) }\end{array}$ & $\begin{array}{l}\text { Full sample } \\
\text { (b) }\end{array}$ & $\begin{array}{l}\text { Full sample } \\
\text { (c) }\end{array}$ & $\begin{array}{c}\text { Sample without default } \\
\text { (d) }\end{array}$ \\
\hline UW Risk & $\begin{array}{l}0.4008^{* * *} \\
(14.35)\end{array}$ & $\begin{array}{c}0.4043^{* * *} \\
(18.45)\end{array}$ & $\begin{array}{l}0.1568^{* * *} \\
(3.971)\end{array}$ & $\begin{array}{l}0.1516^{* * *} \\
\quad(3.772)\end{array}$ \\
\hline Leverage & & $\begin{array}{c}2.2037^{* * *} \\
(8.891)\end{array}$ & $\begin{array}{l}2.0876^{* * *} \\
(8.121)\end{array}$ & $\begin{array}{l}2.0594^{* * *} \\
(8.236)\end{array}$ \\
\hline Equity Volatility & & $\begin{array}{c}1.3949^{* * *} \\
(5.563)\end{array}$ & $\begin{array}{l}1.9510^{* * *} \\
(5.719)\end{array}$ & $\begin{array}{c}1.9340^{* * *} \\
(5.885)\end{array}$ \\
\hline Firm Size & & $\begin{array}{c}-0.276^{* * *} \\
(-7.48)\end{array}$ & $\begin{array}{c}-0.246^{* * *} \\
(-6.34)\end{array}$ & $\begin{array}{c}-0.254^{* * *} \\
\quad(-6.83)\end{array}$ \\
\hline Profitability & & $\begin{array}{c}-2.585^{* * *} \\
(-5.99)\end{array}$ & $\begin{array}{c}-2.429^{* * *} \\
(-5.89)\end{array}$ & $\begin{array}{c}-2.398^{* * *} \\
(-5.85)\end{array}$ \\
\hline Cash & & $\begin{array}{c}0.6920^{* *} \\
(2.149)\end{array}$ & $\begin{array}{l}0.5271 \\
(1.590)\end{array}$ & $\begin{array}{l}0.5154 \\
(1.573)\end{array}$ \\
\hline 1yr Swap & & & $\begin{array}{c}-0.038^{* *} \\
(-2.43)\end{array}$ & $\begin{array}{c}-0.045^{* * *} \\
(-2.94)\end{array}$ \\
\hline CDS Index & & & $\begin{array}{c}0.4078^{* * *} \\
(5.871)\end{array}$ & $\begin{array}{c}0.3831^{* * *} \\
(5.364)\end{array}$ \\
\hline Adj. $R^{2}$ & $\begin{array}{l}0.150 \\
18588\end{array}$ & $\begin{array}{l}0.560 \\
18553\end{array}$ & $\begin{array}{l}0.580 \\
15016\end{array}$ & $\begin{array}{l}0.577 \\
14767\end{array}$ \\
\hline
\end{tabular}




\section{Table V \\ Changes in Underwriter Distress and Credit Risk}

This table shows the impact of changes in underwriter distress on issuer credit risk. $\Delta$ CDS Spread is the relative change in issuer CDS spread from month $t-1$ to month $t$ given in percentages. $\Delta$ UW Risk is the relative change in the log of the related underwriters' average CDS spreads weighted by the number of underwritten bonds outstanding. Specification (d) excludes observations where one of the related underwriters has defaulted within the latest 6 months. The main sample period is 2004-2012, based on monthly observations. When using market measures, the sample period is reduced to $2006-2012$ due to lack of data availability. (*** denotes significance at the $1 \%$ level, ${ }^{* *}$ significance at the $5 \%$ level, and $*$ significance at the $10 \%$ level. The numbers in parentheses are t-statistics.)

\begin{tabular}{|c|c|c|c|c|}
\hline & \multicolumn{4}{|c|}{$\Delta$ CDS Spread } \\
\hline & $\begin{array}{c}\text { Full sample } \\
\text { (a) }\end{array}$ & $\begin{array}{l}\text { Full sample } \\
\text { (b) }\end{array}$ & $\begin{array}{l}\text { Full sample } \\
\text { (c) }\end{array}$ & $\begin{array}{l}\text { Sample without default } \\
\text { (d) }\end{array}$ \\
\hline$\Delta$ UW Risk & $\begin{array}{c}0.2596^{* * *} \\
(5.872)\end{array}$ & $\begin{array}{c}0.2457^{* * *} \\
(5.614)\end{array}$ & $\begin{array}{c}0.1517^{* * *} \\
(3.232)\end{array}$ & $\begin{array}{c}0.1500^{* * *} \\
(3.110)\end{array}$ \\
\hline$\Delta$ Leverage & & $\begin{array}{c}0.2531^{* * *} \\
(3.563)\end{array}$ & $\begin{array}{c}0.1839 * * * \\
(3.107)\end{array}$ & $\begin{array}{c}0.1929^{* * *} \\
(3.233)\end{array}$ \\
\hline$\Delta$ Equity Volatility & & $\begin{array}{c}0.1355^{* * *} \\
(2.931)\end{array}$ & $\begin{array}{c}0.0808^{* * *} \\
(2.636)\end{array}$ & $\begin{array}{c}0.0814^{* * *} \\
(2.639)\end{array}$ \\
\hline$\Delta$ Firm Size & & $\begin{array}{c}-4.444^{* *} \\
(-2.42)\end{array}$ & $\begin{array}{l}-3.053 \\
(-1.57)\end{array}$ & $\begin{array}{c}-3.325^{*} \\
(-1.64)\end{array}$ \\
\hline$\Delta$ Profitability & & $\begin{array}{l}-0.000 \\
(-1.39)\end{array}$ & $\begin{array}{l}-0.000 \\
(-0.79)\end{array}$ & $\begin{array}{l}-0.000 \\
(-0.74)\end{array}$ \\
\hline$\Delta$ Cash & & $\begin{array}{l}0.0008^{* * *} \\
\quad(3.783)\end{array}$ & $\begin{array}{c}0.0009^{* * *} \\
\quad(4.343)\end{array}$ & $\begin{array}{c}0.0009^{* * *} \\
(4.459)\end{array}$ \\
\hline$\Delta$ 1yr Swap & & & $\begin{array}{c}-0.163^{* *} \\
(-2.34)\end{array}$ & $\begin{array}{c}-0.182^{* * *} \\
(-2.63)\end{array}$ \\
\hline$\Delta$ CDS Index & & & $\begin{array}{l}0.6055^{* * *} \\
\quad(11.13)\end{array}$ & $\begin{array}{c}0.6133^{* * *} \\
\quad(10.33)\end{array}$ \\
\hline Adj. $R^{2}$ & 0.129 & 0.161 & 0.335 & 0.334 \\
\hline $\mathrm{N}$ & 18126 & 17576 & 14447 & 14208 \\
\hline
\end{tabular}


Table VI

\section{Credit Ratings and Underwriter Distress Effect}

This table shows the impact of underwriter distress on issuer credit risk conditioned on rating. CDS Spread is the log CDS spread on the five-year contract for the issuing firm. UW Risk is the log of the related underwriters' average CDS spreads weighted by the number of underwritten bonds outstanding. Specification (d) excludes observations for firms where one of the related underwriters has defaulted within the latest 6 months. Issuers are separated into investment-grade rated and speculative-grade rated firms. Investment-grade (Speculative-grade) refers to a firm with a S\&P credit rating that is equal to 'BBB' or higher ('BB' or lower). Specification (a) and (b) show the effect in levels, while specification (c) and (d) is in changes. In all model specifications we use the base regression setup that includes the fundamental determinants of credit risk, as well as the market risk measures. The regressions excludes observations for firms where one of the related underwriters has defaulted within the latest 6 months. The sample period is 2006-2012, based on monthly observations. (*** denotes significance at the $1 \%$ level, ${ }^{* *}$ significance at the $5 \%$ level, and ${ }^{*}$ significance at the $10 \%$ level. The numbers in parentheses are t-statistics.)

\begin{tabular}{|c|c|c|c|c|c|}
\hline & \multicolumn{2}{|c|}{ CDS Spread } & & \multicolumn{2}{|c|}{$\Delta$ CDS Spread } \\
\hline & $\begin{array}{l}\text { Investment-grade } \\
\text { (a) }\end{array}$ & $\begin{array}{c}\text { Speculative-grade } \\
\text { (b) }\end{array}$ & & $\begin{array}{l}\text { Investment-grade } \\
\text { (c) }\end{array}$ & $\begin{array}{c}\text { Speculative-grade } \\
\text { (d) }\end{array}$ \\
\hline UW Risk & $\begin{array}{c}0.1549^{* * *} \\
(4.410)\end{array}$ & $\begin{array}{c}0.2114^{* * *} \\
(3.553)\end{array}$ & $\Delta$ UW Risk & $\begin{array}{c}0.0893^{* *} \\
(2.309)\end{array}$ & $\begin{array}{c}0.3078^{* * *} \\
(2.841)\end{array}$ \\
\hline Leverage & $\begin{array}{c}0.5992^{* *} \\
(2.183)\end{array}$ & $\begin{array}{c}1.4644^{* * *} \\
(6.653)\end{array}$ & $\Delta$ Leverage & $\begin{array}{c}0.2014^{* * *} \\
(3.417)\end{array}$ & $\begin{array}{c}-0.032 \\
(-0.18)\end{array}$ \\
\hline Equity Volatility & $\begin{array}{c}1.4469 * * * \\
(3.774)\end{array}$ & $\begin{array}{c}1.4417^{* * *} \\
\quad(5.273)\end{array}$ & $\Delta$ Equity Volatility & $\begin{array}{c}0.0708^{* *} \\
(2.013)\end{array}$ & $\begin{array}{c}0.1161^{* *} \\
(2.527)\end{array}$ \\
\hline Firm Size & $\begin{array}{c}-0.186^{* * *} \\
(-5.72)\end{array}$ & $\begin{array}{l}-0.059 \\
(-1.03)\end{array}$ & $\Delta$ Firm Size & $\begin{array}{l}-2.540 \\
(-0.96)\end{array}$ & $\begin{array}{l}-4.622 \\
(-1.53)\end{array}$ \\
\hline Profitability & $\begin{array}{c}-1.176^{* * *} \\
(-2.61)\end{array}$ & $\begin{array}{c}-1.627^{* * *} \\
(-3.42)\end{array}$ & $\Delta$ Profitability & $\begin{array}{c}-0.001^{* * *} \\
(-2.87)\end{array}$ & $\begin{array}{c}0.0010^{*} \\
(1.692)\end{array}$ \\
\hline Cash & $\begin{array}{l}-0.081 \\
(-0.27)\end{array}$ & $\begin{array}{l}0.6681 \\
(1.189)\end{array}$ & $\Delta$ Cash & $\begin{array}{c}0.0009 * * * \\
(5.999)\end{array}$ & $\begin{array}{c}-0.020^{* *} \\
(-2.38)\end{array}$ \\
\hline 1yr Swap & $\begin{array}{c}-0.067^{* * *} \\
(-4.40)\end{array}$ & $\begin{array}{l}0.0143 \\
(0.582)\end{array}$ & $\Delta$ 1yr Swap & $\begin{array}{c}-0.182^{* * *} \\
(-2.87)\end{array}$ & $\begin{array}{l}-0.139 \\
(-1.33)\end{array}$ \\
\hline CDS Index & $\begin{array}{c}0.5424^{* * *} \\
(8.208)\end{array}$ & $\begin{array}{c}0.2610^{* * *} \\
(2.614)\end{array}$ & $\Delta$ CDS Index & $\begin{array}{c}0.7026^{* * *} \\
(12.04)\end{array}$ & $\begin{array}{c}0.3555^{* * *} \\
(3.963)\end{array}$ \\
\hline $\begin{array}{l}\text { Adj. } R^{2} \\
\mathrm{~N}\end{array}$ & $\begin{array}{l}0.532 \\
10709\end{array}$ & $\begin{array}{c}0.446 \\
4019\end{array}$ & $\begin{array}{l}\text { Adj. } R^{2} \\
\mathrm{~N}\end{array}$ & $\begin{array}{l}0.366 \\
10347\end{array}$ & $\begin{array}{l}0.327 \\
3825\end{array}$ \\
\hline
\end{tabular}


Table VII

\section{Rollover Risk and Underwriter Distress Effect}

This table shows the impact of rollover exposure and underwriter distress on issuer credit risk. CDS Spread is the log CDS spread on the five-year contract for the issuing firm. UW Risk is the log of the related underwriters' average CDS spreads weighted by the number of underwritten bonds outstanding. Investment-grade (Speculative-grade) refers to a firm with a $\mathrm{S} \& \mathrm{P}$ credit rating that is equal to 'BBB' or higher ('BB' or lower). In Panel A (Panel B) the rollover exposure is proxied by the outstanding debt due in 1, 2, and 3 years, scaled by total assets (total long-term debt). All model specifications use the base regression setup that includes firm fundamentals and market risk measures. The regressions excludes observations for firms where one of the related underwriters has defaulted within the latest 6 months are excluded. The sample period is $2006-2012$, based on monthly observations. (*** denotes significance at the $1 \%$ level, ${ }^{* *}$ significance at the $5 \%$ level, and * significance at the $10 \%$ level. The numbers in parentheses are t-statistics.)

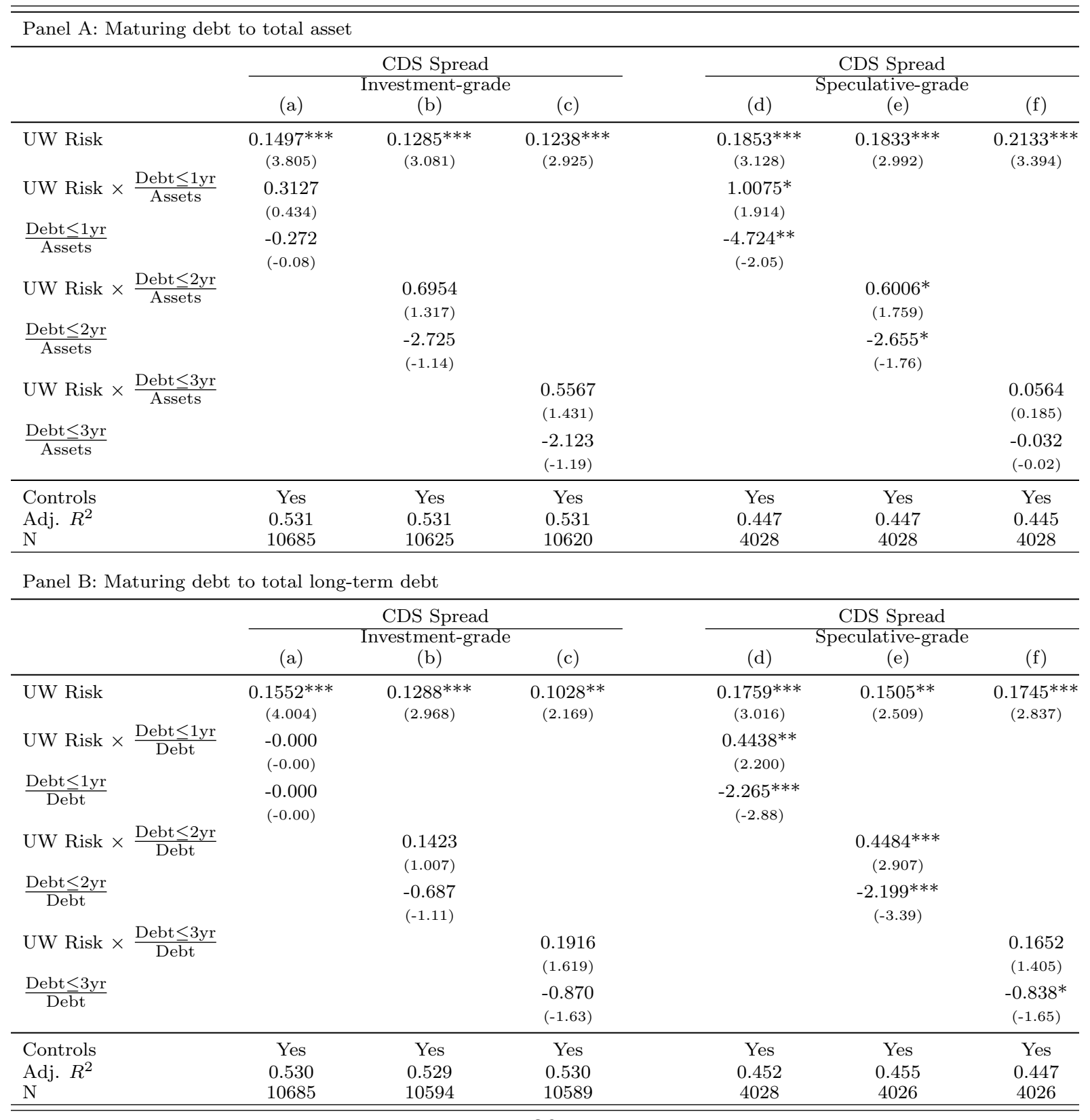




\section{Bond Illiquidity and Underwriter Distress Effect}

This table shows the impact of bond illiquidity and underwriters distress on issuer credit risk. CDS Spread is the log CDS spread on the five-year contract for the issuing firm. UW Risk is the log of the related underwriters' average CDS spreads weighted by the number of underwritten bonds outstanding. Bon illiquidity is proxied by Bid-Ask Spread and is calculated as the average effective bid-ask spread across outstanding bonds from issuer. Investment-grade (Speculative-grade) refers to a firm with a S\&P credit rating that is equal to 'BBB' or higher ('BB' or lower). Panel B uses the bid-ask spread residual obtained from the regressions in Panel A. Rollover exposure is proxied by the ratio of short-term debt scaled by assets. All model specifications use the base regression setup that includes firm fundamentals and market risk measures. The regressions excludes observations for firms where one of the related underwriters has defaulted within the latest 6 months are excluded. The sample period is $2006-2012$ based on monthly observations. (*** denotes significance at the $1 \%$ level, ** significance at the $5 \%$ level, and $*$ significance at the $10 \%$ level. The numbers in parentheses are t-statistics.)

\begin{tabular}{lcc}
\hline \hline Panel A: Underwriter distress effect on bond illiquidity & \\
\hline & Bid-Ask Spread & Bid-Ask Spread \\
\cline { 2 - 3 } & Investment-grade & $\begin{array}{c}\text { Speculative-grade } \\
\text { (b) }\end{array}$ \\
\hline Intercept & -13.902 & -0.237 \\
& $(-3.382)$ & $(-0.049)$ \\
UW Risk & $11.053^{* * *}$ & $8.231^{* * *}$ \\
& $(9.453)$ & $(6.128)$ \\
\hline Controls & No & No \\
Adj. $R^{2}$ & 0.111 & 0.079 \\
$\mathrm{~N}$ & 12152 & 4862 \\
\hline
\end{tabular}

Panel B: Bond illiquidity and underwriter distress effect on corporate credit risk

\begin{tabular}{|c|c|c|c|c|c|c|c|c|}
\hline & \multicolumn{4}{|c|}{ CDS Spread } & \multicolumn{4}{|c|}{ CDS Spread } \\
\hline & (a) & $\begin{array}{l}\text { Investr } \\
\text { (b) }\end{array}$ & $\begin{array}{l}\text { nt-grade } \\
\text { (c) }\end{array}$ & (d) & (e) & $\begin{array}{l}\text { Specula } \\
\text { (f) }\end{array}$ & $\begin{array}{l}\text { ve-grade } \\
\text { (g) }\end{array}$ & (h) \\
\hline Bid-Ask Spread & $\begin{array}{c}0.002^{* * *} \\
(3.039)\end{array}$ & & & & $\begin{array}{c}0.002^{* *} \\
(2.467)\end{array}$ & & & \\
\hline UW Risk & & $\begin{array}{c}0.172^{* * *} \\
(4.798)\end{array}$ & $\begin{array}{c}0.168^{* * *} \\
(4.212)\end{array}$ & $\begin{array}{c}0.168^{* * *} \\
(4.203)\end{array}$ & & $\begin{array}{c}0.251^{* * *} \\
(4.178)\end{array}$ & $\begin{array}{c}0.221^{* * *} \\
(3.642)\end{array}$ & $\begin{array}{c}0.212^{* * *} \\
(3.579)\end{array}$ \\
\hline Bid-Ask Residual & & $\begin{array}{c}0.001^{* * * *} \\
(2.803)\end{array}$ & $\begin{array}{l}0.001^{*} \\
(1.737)\end{array}$ & $\begin{array}{l}0.001 \\
(1.635)\end{array}$ & & $\begin{array}{l}0.002^{* * * *} \\
(2.596)\end{array}$ & $\begin{array}{l}0.002^{*} \\
(1.715)\end{array}$ & $\begin{array}{c}0.002^{* *} \\
(2.017)\end{array}$ \\
\hline $\begin{array}{l}\text { UW Risk } \\
\times \frac{\text { Debt } \leq 1 \mathrm{yr}}{\text { Assets }}\end{array}$ & & & $\begin{array}{l}0.305 \\
(0.406)\end{array}$ & & & & $\begin{array}{l}0.952^{*} \\
(1.695)\end{array}$ & \\
\hline $\begin{array}{l}\text { Bid-Ask Residual } \\
\times \frac{\text { Debt } \leq 1 \mathrm{yr}}{\text { Assets }}\end{array}$ & & & $\begin{array}{l}0.019 \\
(1.383)\end{array}$ & & & & $\begin{array}{l}0.015 \\
(1.377)\end{array}$ & \\
\hline $\begin{array}{l}\text { UW Risk } \\
\quad \times \frac{\text { Debt } \leq 1 \mathrm{yr}}{\text { Debt }}\end{array}$ & & & & $\begin{array}{l}0.057 \\
(0.366)\end{array}$ & & & & $\begin{array}{c}0.423^{* *} \\
(2.101)\end{array}$ \\
\hline $\begin{array}{l}\text { Bid-Ask Residual } \\
\times \frac{\text { Debt } \leq 1 \mathrm{yr}}{\text { Debt }}\end{array}$ & & & & $\begin{array}{l}0.006 \\
(1.520)\end{array}$ & & & & $\begin{array}{l}0.001 \\
(0.274)\end{array}$ \\
\hline$\frac{\text { Debt }<1 \mathrm{yr}}{\text { Assets }}$ & & & $\begin{array}{l}-0.054 \\
(-0.01)\end{array}$ & & & & $\begin{array}{c}-4.532^{*} \\
(-1.79)\end{array}$ & \\
\hline$\frac{\text { Debt }<1 \mathrm{yr}}{\text { Debt }}$ & & & & $\begin{array}{l}-0.159 \\
(-0.24)\end{array}$ & & & & $\begin{array}{c}-2.215^{* * *} \\
(-2.85) \\
\end{array}$ \\
\hline Controls & Yes & Yes & Yes & Yes & Yes & Yes & Yes & Yes \\
\hline Adj. $R^{2}$ & 0.531 & 0.535 & 0.535 & 0.533 & 0.428 & 0.448 & 0.450 & 0.455 \\
\hline $\mathrm{N}$ & 10020 & 9919 & 9900 & 9900 & 3821 & 3790 & 3760 & 3760 \\
\hline
\end{tabular}


Table IX

\section{Economic Significance of Underwriter Distress}

This table shows the economic significance of underwriter distress. The estimation is based upon the results obtained in Table VIII, specification (c) and (g). The absolute credit risk contribution is estimated as the difference between the $50 \%$ and $5 \%$ percentile in the distribution of the respective component. The relative credit risk contribution is estimated as the difference between issuer specific components and the $5 \%$ percentile scaled by the size of CDS spread (bps). The key variable of interest is the underwriter distress contribution (column 1) which is defined as

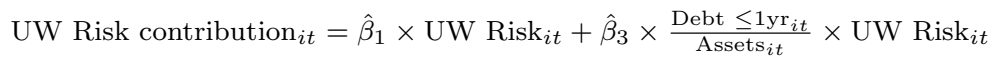

The bid-ask spread residual contribution is estimated following the same approach and refers to the bond illiquidity effect that is unrelated to the underwriter distress effect. The table also shows the economic significance of Leverage, Equity Volatility, Firm size and Profitability.

\begin{tabular}{|c|c|c|c|c|c|c|}
\hline \multicolumn{7}{|c|}{ Panel A: Absolute CDS Spread contribution } \\
\hline & UW Risk & $\begin{array}{l}\text { Bid-Ask } \\
\text { Residual }\end{array}$ & Leverage & $\begin{array}{c}\text { Equity } \\
\text { Volatility }\end{array}$ & Firm Size & Profitability \\
\hline & (a) & (b) & (c) & (d) & (e) & (f) \\
\hline Investment-grade & 0.351 & 0.040 & 0.065 & 0.050 & 0.366 & 0.215 \\
\hline Speculative-grade & 0.460 & 0.060 & 0.336 & 0.073 & 0.092 & 0.236 \\
\hline \multicolumn{7}{|c|}{ Panel B: Relative CDS Spread contribution } \\
\hline & & Bid-Ask & & Equity & & \\
\hline & UW Risk & Residual & Leverage & Volatility & Firm Size & Profitability \\
\hline & (a) & (b) & (c) & (d) & $(\mathrm{e})$ & $(\mathrm{f})$ \\
\hline Investment-grade & $7.784 \%$ & $1.011 \%$ & $1.611 \%$ & $1.232 \%$ & $8.993 \%$ & $5.142 \%$ \\
\hline Speculative-grade & $7.978 \%$ & $1.105 \%$ & $6.319 \%$ & $1.307 \%$ & $1.576 \%$ & $4.233 \%$ \\
\hline
\end{tabular}




\section{Table X \\ Key Credit Events for Defaulted Underwriters}

This table lists the key events leading up to the default of underwriters that are included in our sample of the 20 most active lead underwriters. These are Bear Stearns (Panel A), Lehman Brothers (Panel B) and Wachovia (Panel C).

\begin{tabular}{ll}
\hline \hline Panel A: Bear Stearns & \\
\hline Jun-2007 & Bear Stearns commits $\$ 1.6$ bn in secured loans to bail out its hedge Bear Stearns High-Grade \\
Jul-2007 & The Bear Stearns High-Grade Structured Credit Fund has lost more than $90 \%$ of its value, while \\
& another hedge fund, Bear Stearns High-Grade Structured Credit Enhanced Leveraged Fund, \\
& looses all of its value. In the end, both hedge funds filed for Chapter 15 bankruptcy. \\
Dec-2007 & The bank reports its first ever quarterly loss, which is nearly four times the analysts' forecasts. \\
Mar-2008 & to large Capital Corporation (CCC), a hedge fund partly owned by Bear Stearns, collapses due \\
& Consequently, and due to its exposure to the hedge fund and investors grown anxiousness, Bear \\
& Stearns shares fall by $17 \%$. On March 14,2008, JP Morgan and the New York Federal Reserve \\
& rush to the rescue Bear Stearns, while its' shares crashes by almost $50 \%$. JP Morgan agrees \\
& to buy Bear Stearns in a deal that values Bear Stearns shares at $\$ 2$ each, with JP Morgan \\
& exchanging 0.05473 of each of its shares for one Bear share. Due to legal challenges against the \\
& low share price offer claimed by some of Bear Stearns' shareholders, JP Morgan raises its offer \\
& for Bear Stearns to $\$ 10$ a share for the takeover.
\end{tabular}

Panel B: Lehman Brothers

Dec-2007 Lehman Brothers bypasses Bear Stearns as the largest underwriter of mortgage-backed securities. However, at the same time, it closes one of its subprime-lending units which eliminates approximately 1,200 jobs.

Mar-2008 Due to the concern that Lehman Brothers would be the next Wall Street financial institution to collapse after Bear Stearns, the shares fall as much as $48 \%$. However, most of Lehman Brothers' stock losses recover in the following weeks.

Jun-2008 Lehman Brothers announces its first quarterly loss since going public and sells $\$ 6$ billion of stock to bolster capital.

Aug-2008 Shares drop $13 \%$ due to the announcement that Lehman Brothers solicited buyers for its investment-management division.

Sep-2008 Lehman Brothers shares plunged by additionally $45 \%$ after a dismissed capital infusion and reports a $\$ 3.9$ billion third-quarter loss, the largest in its history. Accordingly, it announces plans to sell a majority stake in its asset-management unit and to spin off commercial realestate holdings. In collaboration with the U.S. Treasury and Federal Reserve, Bank of America Corp. emerges as potential buyer. On September 12, 2008, Moody's announces a potential credit downgrade and outlines the need for a "stronger financial partner" which lead to an immediate drop in Lehman Brothers' shares of $42 \%$. Government agencies react by urging Wall Street chiefs to find a solution. In an effort to prevent the liquidation of Lehman Brothers, finance leaders meet at the Federal Reserve Bank of New York on September 13, 2008, and Bank of America and Barclays emerge as bidders. However, due to a fail to secure guarantees against losses, both bidders withdraws from their offer the following day. On September 15, 2008, Lehman Brothers petitioned for Chapter 11 bankruptcy and listed $\$ 639$ billion of assets in the largest filing in U.S. history.

Panel C: Wachovia

\begin{tabular}{ll}
\hline Apr-2008 & Wachovia announces first quarterly loss in seven years. \\
Sep-2008 & Wachovia experienced large outflows of deposits and drops in the stock price due to the collapse \\
& of Washington Mutual, the largest US savings and loan association. As a reaction to the FDIC's \\
& declaration that Wachovia was "systemically important" to the health of the economy, and thus \\
& could not be allowed to fail, Citigroup agreed to takeover Wachovia's banking operations for $\$ 1$ \\
& per share. \\
& Though the liquidity provision by Citigroup would have allowed Wachovia to continue its op- \\
& erations, Wells Fargo and Wachovia announced on October 3, 2008, their merge in an all-stock \\
& transaction requiring no government involvement. The agreement included a purchase of Wa- \\
& chovia in entirety for $\$ 15.1$ billion (approximately $\$ 7$ per share) and Wells Fargo's purchase of \\
& Wachovia was closed on December 31,2008 . In the meanwhile, Citigroup filed a $\$ 60$ billion law- \\
& suit against Wachovia and Wells Fargo for interfering with Citigroup's takeover of Wachovia's \\
& banking operations.
\end{tabular}




\section{Table XI}

\section{Underwriter Default and Issuer Credit Risk}

This table shows the impact of underwriter default on issuer credit risk. CDS Spread is the log CDS spread on the five-year contract for the issuing firm. Default Dummy is a dummy that is equal to one after the underwriter defaults. Panel A is for the default of Bear Stearns which happend on March 14, 2008. Likewise, Panel B and Panel C, is for the defaults of Lehman Brothers and Wachovia. Lehman Brothers defaulted on September 15, 2008, and Wachovia on September 29, 2008. In specification (a), the dummy is only equal to one in the month following the underwriter default. In specification (b), (c), (d), (e), and (f), the dummy is equal to one in the month following the underwriter default and then also $2,3,4,5$, and 6 month after. In all model specifications, we use the sub-sample of firms that have a relationship to the underwriter and perform the regression on the CDS spread with former specified base regression. (*** denotes significance at the $1 \%$ level, ${ }^{* *}$ significance at the $5 \%$ level, and $*$ significance at the $10 \%$ level. The numbers in parentheses are t-statistics.)

\begin{tabular}{|c|c|c|c|c|c|c|}
\hline \multicolumn{7}{|c|}{ Panel A: Bear Stearns } \\
\hline & \multicolumn{6}{|c|}{ CDS Spread } \\
\hline & $\begin{array}{l}1 \text { mth. } \\
\text { (a) }\end{array}$ & $\begin{array}{l}\text { 1-2 mth. } \\
\text { (b) }\end{array}$ & $\begin{array}{l}\text { 1-3 mth. } \\
\text { (c) }\end{array}$ & $\begin{array}{c}1-4 \text { mth. } \\
\text { (d) }\end{array}$ & $\begin{array}{c}1-5 \text { mth. } \\
\text { (e) }\end{array}$ & $\begin{array}{c}1-6 \text { mth. } \\
\text { (f) }\end{array}$ \\
\hline Default Dummy & $\begin{array}{c}0.1828^{* * *} \\
(8.360)\end{array}$ & $\begin{array}{c}0.1535^{* * *} \\
(3.743)\end{array}$ & $\begin{array}{c}0.1257^{*} \\
(1.757)\end{array}$ & $\begin{array}{l}0.1209 \\
(1.642)\end{array}$ & $\begin{array}{c}0.1251^{*} \\
(1.691)\end{array}$ & $\begin{array}{l}0.1197 \\
(1.549)\end{array}$ \\
\hline Controls & Yes & Yes & Yes & Yes & Yes & Yes \\
\hline Adj. $R^{2}$ & 0.842 & 0.842 & 0.842 & 0.842 & 0.842 & 0.842 \\
\hline $\mathrm{N}$ & 396 & 396 & 396 & 396 & 396 & 396 \\
\hline
\end{tabular}

Panel B: Lehman Brothers

\begin{tabular}{lcccccc}
\hline & \multicolumn{7}{c}{ CDS Spread } \\
\cline { 2 - 7 } & $\begin{array}{c}1 \mathrm{mth} \\
\text { (a) }\end{array}$ & $\begin{array}{c}1-2 \mathrm{mth} . \\
\text { (b) }\end{array}$ & $\begin{array}{c}1-3 \mathrm{mth} . \\
\text { (c) }\end{array}$ & $\begin{array}{c}1-4 \mathrm{mth} . \\
\text { (d) }\end{array}$ & $\begin{array}{c}1-5 \mathrm{mth} . \\
(\mathrm{e})\end{array}$ & $\begin{array}{c}1-6 \mathrm{mth} . \\
(\mathrm{f})\end{array}$ \\
\hline Default Dummy & 0.0495 & $0.1129^{* *}$ & $0.1592^{* * *}$ & $0.1239^{* *}$ & 0.0462 & -0.010 \\
& $(1.405)$ & $(1.985)$ & $(2.586)$ & $(2.158)$ & $(0.727)$ & $(-0.11)$ \\
\hline Controls & Yes & Yes & Yes & Yes & Yes & Yes \\
Adj. $R^{2}$ & 0.651 & 0.652 & 0.652 & 0.652 & 0.651 & 0.651 \\
N & 1813 & 1813 & 1813 & 1813 & 1813 & 1813 \\
\hline
\end{tabular}

Panel C: Wachovia

\begin{tabular}{lcccccc}
\hline & \multicolumn{7}{c}{ CDS Spread } \\
\cline { 2 - 7 } & $\begin{array}{c}1 \mathrm{mth} . \\
(\mathrm{a})\end{array}$ & $\begin{array}{c}1-2 \mathrm{mth} . \\
\text { (b) }\end{array}$ & $\begin{array}{c}1-3 \mathrm{mth} \\
(\mathrm{c})\end{array}$ & $\begin{array}{c}1-4 \mathrm{mth} . \\
\text { (d) }\end{array}$ & $\begin{array}{c}1-5 \mathrm{mth} . \\
(\mathrm{e})\end{array}$ & $\begin{array}{c}1-6 \mathrm{mth} . \\
(\mathrm{f})\end{array}$ \\
\hline \multirow{2}{*}{ Default Dummy } & $0.2178^{* * *}$ & $0.2481^{* * *}$ & $0.2276^{* * *}$ & 0.1387 & 0.0477 & -0.108 \\
& $(2.995)$ & $(3.358)$ & $(3.002)$ & $(1.347)$ & $(0.347)$ & $(-0.65)$ \\
\hline Controls & Yes & Yes & Yes & Yes & Yes & Yes \\
Adj. $R^{2}$ & 0.581 & 0.582 & 0.582 & 0.581 & 0.580 & 0.580 \\
$\mathrm{~N}$ & 1208 & 1208 & 1208 & 1208 & 1208 & 1208 \\
\hline \hline
\end{tabular}




\section{Table XII}

\section{Bond Underwriter versus Bank Loan Provider}

This table shows the impact of bond underwriter distress versus bank loan provider distress. CDS Spread is the log CDS spread on the five-year contract for the issuing firm. UW Risk is the log of the related underwriters' average CDS spreads weighted by the number of underwritten bonds outstanding. Likewise, Bank Risk is related bank syndicate members' CDS weighted spreads. The regression setup is similar to the base regression but including the additional bank risk variables. Bond debt to total debt is the ratio of outstanding corporate bond debt to the sum of bond and bank loan debt. All observations for firms where one of the related underwriters has defaulted within the latest 6 months are excluded. Further, only firms for which we have lender information from SDC Dealscan are included. The sample period is 2006-2012, based on monthly observations. (*** denotes significance at the $1 \%$ level, $* *$ significance at the $5 \%$ level, and ${ }^{*}$ significance at the $10 \%$ level. The numbers in parentheses are t-statistics.)

\begin{tabular}{|c|c|}
\hline & CDS Spread \\
\hline$\frac{\text { Bond Debt }}{\text { Total Debt }}$ & $\begin{array}{c}-0.939^{*} \\
(-1.74)\end{array}$ \\
\hline UW Risk $\times \frac{\text { Bond Debt }}{\text { Total Debt }}$ & $\begin{array}{l}0.2104^{* * *} \\
(3.177)\end{array}$ \\
\hline Bank Risk $\times \frac{\text { Bank Debt }}{\text { Total Debt }}$ & $\begin{array}{c}0.2013^{* *} \\
(2.524)\end{array}$ \\
\hline Leverage & $\begin{array}{l}1.6410^{* * *} \\
(6.173)\end{array}$ \\
\hline Equity Volatility & $\begin{array}{l}2.2336^{* * *} \\
(5.243)\end{array}$ \\
\hline Firm Size & $\begin{array}{c}-0.158^{* * *} \\
(-3.36)\end{array}$ \\
\hline Profitability & $\begin{array}{c}-2.593^{* * *} \\
(-4.90)\end{array}$ \\
\hline Cash & $\begin{array}{l}0.5013 \\
(0.978)\end{array}$ \\
\hline 1yr Swap & $\begin{array}{c}-0.056 * * * \\
(-2.61)\end{array}$ \\
\hline CDS Index & $\begin{array}{c}0.1524^{*} \\
(1.696)\end{array}$ \\
\hline $\begin{array}{l}\text { Adj. } R^{2} \\
\mathrm{~N}\end{array}$ & $\begin{array}{l}0.614 \\
5183\end{array}$ \\
\hline
\end{tabular}

